\title{
Strategi Adaptasi Nelayan di Pulau-Pulau Kecil terhadap Dampak Perubahan Iklim \\ (Kasus: Desa Pulau Panjang, Kecamatan Subi, Kabupaten Natuna, Kepulauan Riau)
}

\author{
Fisher's Adaptation Strategiesinsmall islandsto the Impactsof Climate Change (A case study in \\ Pulau Panjang Village, Subi District, Natuna Regency, Riau Island)
}

Ari Wibowo*) dan Arif Satria

Departemen Sains Komunikasi dan Pengembangan Masyarakat, Fakultas Ekologi Manusia, Institut Pertanian Bogor

*) E-mail: ari.skpmipb@gmail.com\&arifsatria@gmail.com

\begin{abstract}
This study aime to analyzethe effect ofclimate change onsocio-economic conditionsof fisher, as well as to identifyadaptation and mitigation strategies related to climate change. The method inthis study usingquantitative and qualitative methods. The results showed thattheeffectof climate changeonsocio-economic aspects offishing. Influenceonsocio-economic aspects ofthesearenotnecessarilythe calendarseason, the loss of some of the animalsthat becamea markerdeterminationseason, andincreased intensity of stormsat seawhichinterfere withthe activityof fisher catching. Therefore, the right strategy is needed to transform fisher's adaptation on adjusting with climate change. The types of adaptational strategy are divided into: the diversification of economic activities; the investment on fishing technology; maintaining good relationship with other fishers; finding new catchment areas; and utilizing social relationship and mobilizing members of the family.
\end{abstract}

Keywords: adaptationstrategy, climate change,fisher, small islands

\section{PENDAHULUAN}

Isu perubahan iklim akhir-akhir ini menjadi isu menarik diperbincangkan baik ditingkat global maupun lokal. Indonesia adalah Negara yang memiliki kerentanan tinggi terhadap perubahan iklim (Diposaptono etal et.al 2009). Saad (2013) menyatakan bahwa hal ini berkaitan dengan Indonesia yang merupakan wilayah kepulauan terbesar di dunia dengan dengan jumlah Pulau Sebanyak 17.504 pulau. Dari jumlah tersebut ternyata hanya sekitar 12,38 persen atau sekitar 2.342 pulau saja yang berpenghuni. Sisanya 87,62 persen atau sebanyak 15.337 pulau tidak berpenghuni. Kerentanan Indonesia juga disebakan faktor aktifitas manusia yang kurang peduli terhadap aspek keberlanjutan lingkungan, yang terlihat konversi hutan secara besarbesaran tanpa mengindahkan keberlanjutannya, penggunaan bahan bakar fosil, dan pembukaan mangrove di wilayah pesisir serta perusakan terumbu karang yang masif dilakukan (Hidayati 2011).

Diposaptono et.al (2009) menyebutkan bahwa perubahan iklim mengakibatkan perubahan fisik lingkungan di wilayah pesisir dan pulau-pulau kecil antara lain berupa intrusi air laut ke darat, gelombang pasang, banjir, kekeringan, genangan di lahan rendah, dan erosi pantai. Perubahan fisik tersebut tentunya mengimbas pada segala sektor kehidupan dan penghidupan di wilayah pesisir dan pulau-pulau kecil. Perubahan fisik tersebut berdampak pada morfologi pantai, ekosistem alamiah, permukiman, sumberdaya air, perikanan dan kondisi sosial-ekonomi maupun budaya masyarakat.

Melihat dampak perubahan iklim di Indonesia, kategori masyarakat yang paling rentan adalah masyarakat di pedesaan khususnya masyarakat pesisir dan pulau-pulau kecil(Numberi 2009). Pada dasarnyanelayan dalam kegiatan sehari-hari sangat bergantung pada tabiat alam. Perubahan pada alam yang drastis dan yang sulit untuk diantisipasi, selanjutnya akan menambah kepanikan terhadap kejutan alam yang siap melenyapkan tanaman atau hasil tangkapan mereka. Masyarakat nelayan hidup dalam ketidakpastian hasil matapencahariannya, karena mereka bergantung pada alam (musim dan cuaca). Dengan adanya imbas dari perubahan iklim yang berpengaruh secara langsung terhadap lingkungannya, menjadikan ketidakpastian tersebut semakin meningkat terhadap aspek penghidupan nelayan.

Perhatian pemerintah terkait adaptasi dan mitigasi terhadap perubahan iklim diatur dalam Peraturan Menteri Dalam Negeri Nomor 30 Tahun 2010 TentangPedoman Pengelolaan Sumber Daya Di Wilayah Lautbagian ke-empat pasal 18 menegaskan Pemerintah Daerah dalam menyusun perencanaan pengelolaan sumber daya di wilayah laut, wajib memasukkan materi yang memuat upaya adaptasi dan mitigasi dampak perubahan iklim. Selanjutnya disebut pada pasal 19 bahwa Adaptasi dan mitigasi perubahan iklim dilakukan dengan melibatkan Pemerintah, Pemerintah Daerah, dan/atau masyarakat. Pasal 
20 memantapkan lagi dengan penjelasan penyelenggaraan adaptasi dan mitigasi perubahan iklim sebagaimana dimaksud dalam Pasal 18 dilaksanakan dengan memperhatikan aspek: sosial, ekonomi, dan budaya masyarakat; kelestarian lingungan hidup;kemanfaatan dan efektivitas; sertalingkup luas wilayah.

Berdasarkan hasil pemaparan kondisi masyarakat nelayan Indonesia dan adanya perubahan iklim yang terjadi, sebagai bentuk solusi kongkrit dalam memberikan daya dukung terhadap masyarakat dan lingkungan, perlu adanya kajian khusus yang tepat bagi masyarakat dalam beradaptasi dengan perubahan tersebut. Pelaksanaan strategi adaptasi yang tepat dalam menghadapi perubahan iklim perlu disiapkan, sehingga masyarakat tidak rentan dengan dampak laju perubahan yang terjadi. Berbagai bentuk strategi adaptasi yang tepat dalam menanggapi adanya perubahan iklim ini perlu diantisipasi semua aktor baik itu pemerintah, swasta dan masyarakat sendiri. Oleh karena itu, pertanyaan mendasar dari penelitian ini adalah,Bagaimana strategi adaptasi yang dilakukan masyarakat nelayan pulau-pulau kecil dalam menghadapi dampak perubahan iklim?

Berdasarkan latar belakang di atas, maka rumusan masalah yang akan dibahas dalam penelitian ini yaitu:

1. Bagaimana pengaruh perubahan iklim terhadap kondisi sosial - ekonomi nelayan Desa Pulau Panjang?

2. Bagaimana strategi adaptasi yang dilakukan nelayan Desa Pulau Panjang dalam menghadapi dampak perubahan perubahan iklim?

Berdasarkan rumusan masalah di atas, tujuan penelitian ini yaitu:

1. Menganalisis pengaruh perubahan iklim terhadap kondisi sosial - ekonomi nelayan Desa Pulau Panjang.

2. Mengidentifikasi strategi adaptasi yang dilakukan nelayan Desa Pulau Panjang dalam menghadapi dampak perubahan perubahan iklim.

Penelitian ini diharapkan dapat memberi manfaat bagi berbagai pihak:

1. Bagi akademisi, penelitian ini dapat menjadi referensi lebih lanjut mengenai adaptasi nelayan terhadap perubahan iklim di kawasan pesisir dan pulau-pulau kecil khususnya.

2. Bagi masyarakat luas, hasil penelitian ini dapat menjadi model pola adaptasi yang dapat bermanfaat bagi pengembangan adaptasi-mitigasi perubahan iklim pada pulau-pulau kecil di berbagai wilayah pesisir di dunia.

3. Bagi pemerintah, penilitian ini dapat dijadikan informasi yang dapat mempengaruhi pengambilan keputusan yang menentukan kebijakan pembangunan, terutama pembangunan di sektor perikanan.

\section{PENDEKATAN TEORITIS}

\section{Perubahan Iklim}

Konvensi PBB (1990) mengenai perubahan iklim yang menyatakan: "Climate change means a change of climate which is attributed directly or inderictly to human activities that alters the composition of the global atmosphere and which is in addition to natural climate variability observed over comparable time periods. Diposaptono et.al., (2009) menjelaskan perubahan iklim adalah perubahan pada unsur-unsur dalam jangka waktu yang panjang (50-100 tahun) yang dipengaruhi oleh kegiatan manusia yang menghasilkan emisi gas rumah kaca(GRK). Daripenjelasan Diposaptono terlihat bahwa anomali iklim yang terjadi pada waktu yang singkat bukanlah disebut sebagai perubahan iklim. Apabila memaknai perubahan iklim dengan kedua definisi tersebut, perubahan iklim adalah perubahan unsurunsur iklim yang terjadi pada periode waktu yang panjang dan dapat dibandingkan. Contohnya dengan mengamati data suhu dan melihat ada kecenderungan naik dari waktu ke waktu tertentu dan fluktuasinya semakin membesar, atau anomali iklim semakin sering terjadi dibanding periode waktu sebelumnya, maka dapat dikatakan perubahan iklim sudah terjadi.

Tomkins dan Adger (2004) menjelaskan bahwa manifestasi inti dari perubahan iklim meliputi perubahan bertahap dalam suhu dan curah hujan rata-rata, rentang yang lebih besar dalam variasi musiman dan antar-tahunan, peningkatan frekuensi dan intensitas kejadian ekstrem, serta transformasi potensi bencana ekosistem. Makna perubahan iklim menurut Tomkins dan Adger lebih menitik beratkan indikatorindikatornya yang terjadi tidak dalam waktu yang singkat. Tomkins dan Adger dalam penjelasannya tersebuk juga memaknai perubahan iklim sampai pada sisi dampaknya.

Satria (2009) perubahan iklim bersumber dari tingkat global dimana pemanasan global sebagai akibat meningkatnya emisi karbon (CO2) yang dapat mencairkan es di kutub dan meningkatkan permukaan air laut. Satria juga menambahkan, Pemanasan global terjadi akbibat peningkatan suhu global karena terjadinya efek rumah kaca yang disebabkan oleh meningkatnya emisi gas-gas seperti Karbondioksida (CO2), Metana (CH4) dan CFC sehingga energy matahari terperangkap dalam atmosfer bumi. Jadi, perubahan iklim global adalah akumulasi dari aktivitas ekonomi yang bersumber dari energi fosil dan juga deforestasi yang makin parah.

\section{Dampak Perubahan Iklim terhadap Kondisi Ekologi}

Perubahan iklim global mengakibatkan kerugian yang sangat besar di tingkat lokal. Perubahan iklim berimbas pada segala sektor khususnya wilayah pesisir. Masyarakat yang paling rentan dalam perubahan iklim adalah masyarakat wilayah pesisir dan pulau-pulau kecil (Diposaptono et.al 2009 dan Satria 2009). Indonesia memiliki 17.480 pulau dan 65 persen pulau-pulau yang ada di Indonesia merupakan pulau-pulau kecil yang sangat rentan terhadap dampak perubahan iklim. Hingga saat ini telah tercatat sebanyak 24 pulau-pulau kecil di Indonesia hilang disebabkan oleh tsunami, abrasi dan kegiatan pertambangan pasir yang tidak terkendali. Indikator dan Dampak-dampak perubahan iklim terhadap lingkungan sebagai berikut (Priwardhani 2013; dan Diposaptono et.al 2009):

1. Indikator perubahan suhu tahunan dan periode 20 tahun terakhir berdampak sebagai berikut: 
a. Melelehnya kutub, sehingga naiknya paras muka air laut

b. Coral Bleaching (kematian \& pemutihan terumbu karang) selain akibat juga dari penggunaan kimia potassium

2. Indikator perubahan volume curah hujan tahunan dan periode 20 tahun terakhir berdampak pada Hujan badai, banjir bandang dan abrasi.

3. Indikator Kenaikan volume air laut berdampak pada genangan di lahan rendah dan rawa, Erosi pantai, Gelombang Ekstrim dan banjir, Intrusi Air laut ke sungai dan air tanah.

\section{Dampak Perubahan Iklim terhadap Sosial dan Ekonomi Nelayan}

Perubahan iklim yang terjadi juga berdampak pada kondisi sosial, budaya dan ekonomi nelayan. Indikator dan Dampak-dampak perubahan iklim terhadap sosial, budaya dan ekonomi nelayan sebagai berikut (Surtiari 2011; Priwardhani 2013; dan Diposaptono et.al 2009):

1. Indikator perubahan pola musim dan pola angin yang dianutnelayan menyebabkan nelayan sulitmemperkirakan kondisi laut, menggangu kegiatan kenelayanan dan keselamatan nelayan.

2. Dengan indikator hilangnya beberapa hewan yang menjadi penanda pergantian musim, bergesernya waktu dimulai dan berakhirnya musim, tidak terlacaknya angin dan gelombang yang telah dipercayai menjadi penada awal dan berakhirnya musim, berubahnya kecepatan angin pada musim-musim tertentu serta jangka waktu terjadinya angin dan gelombang pada musim tertentu berdampak pada ketidakpastian waktu untuk melaut.

\section{Kondisi Sosial-Budaya \& Ekonomi Nelayan Pulau Kecil di Indonesia}

Satria (2002) menjelaskan masyarakat pesisir adalah sekumpulan masyarakat yang bersama-sama mendiami wilayah pesisir membentuk dan memiliki kebudayaan yang khas yang terkait dengan ketergantungan pada pemanfaatan sumberdaya pesisir. Selanjutnya juga dijelaskan bahwa masyarakat pesisir bukan hanya nelayan, melainkan juga pembudidaya ikan, pengolah ikan bahkan pedagang ikan. Masyarakat pesisir dan pulau-pulau kecil memiliki karakteristik sistem ekonomi dan sosial-budaya yang tidak jauh berbeda dengan nelayan pada umumnya. Tapi yang membedakan solidaritas masyarakat pesisir pada umumnya dan pulau-pulau kecil, mayarakat pesisir di pulau-pulau kecil sangat kuat solidaritas sosialnya dikarenakan kondisi geografi dan akses yang menjadikan mereka harus berjuang bersama dalam bertahan hidup. Masyarakat pulau-pulau kecil berhadapan pada kondisi yang hampir aspek kehidupannya berhubungan dengan laut. Terlihat dari transportasi, masuknya logistik, dan sumber mata pencaharian serta SDA terbesar adalah hasil dari laut.

Nelayan yang bermatapencaharian di laut sering dihadapkan pada ketidak pastian dan kondisi ekologis yang sulit dikontrol. Polnack dalam Satria (2001), menjelaskan bahwa nelayan berbeda dengan petani, dimana mereka dihadapkan pada situasi ekologis yang sulit di kontrol produknya mengingat perikanan tangkap bersifat open akses sehingga nelayan harus berpindah-pindah dan ada elemen risiko yang harus dihadapi lebih besar daripada yang dihadapi petani. Selain itu juga dijelaskan bahwa, nelayan juga harus berhadapan dengan kehidupan laut yang keras sehingga membuat mereka umumnya bersikap keras, tegas dan terbuka, yang membedakannya dengan petani. Dalam hal ini penulis belum menemukan studi yang membedakan petani dan nelayan dari segi budayanya, maka penulis lebih memaparkan secara komprehensif.

Dalam mengkaji masyarakat pesisir, masyarakat desa terisolasi (masyarakat pulau kecil) dan masyarakat desa pantai disebutkan Satria (2002) sebagai gambaran wujud komunitas kecil. Satria (2002) juga mengutip dari Koentjaraningrat (1990), bahwa komunitas kecil tersebut memiliki ciri-ciri yaitu:

1. mempunyai identitas yang khas (distinctiveness),

2. terdiri dari jumlah penduduk dengan jumlah yang cukup terbatas (smallness) sehingga masih saling mengenal sebagai individu yang berkepribadian,

3. bersifat seragam dengan diferensiasi terbatas (homogeneity),

4. kebutuhan hidup penduduknya sangat terbatas sehingga semua dapat dipenuhi sendiri tanpa bergantung pada pasar di luar (all-providing self sufficiency).

Dalam mengkaji nelayan, Satria (2001) menjelaskan bahwa penting untuk membedakan sejelas mungkin antara [1] nelayan sebagai status pekerjaan (occupational status) dan [2] nelayan sebagai komunitas. Nelayan sebagai status pekerjaan berkaitan dengan pengelolaan sumberdaya perikanan (fisheries management) dan penting membedakan nelayan ekonomi skala kecil dan nelayan besar. Polnack dalam Satria (2001), membedakan karakteristik nelayan skala besar (large scale fisherman) dan skala kecil (small scale fisherman).

“...Ciri perikanan skala besar adalah (a) diorganisasi dengan cara-cara yang mirip dengan perusahaan agroindustry di Negara-negara maju; (b) secara relative lebih padat modal; (c) memberikan pendapatan yang lebih tinggi daripada perikan sederhana, baik untuk pemilik maupun awak perahu; dan (d) menghasilkan untuk ikan kaleng dan ikan beku yang berorientasi ekspor. Sementara itu, perikanan skala kecil lebih beroprasi di daerah pesisir yang tumpang tindih dengan kegiatan budidaya. Pada umumnya, mereka bersifat padat karya... ....Nelayan kecil mencakup berbagai karakteristik nelayan, baik kapasitas teknologi alat tangkap dan armada maupun budaya."

Terlihat bahwa karakteristik nelayan kecil mereka masih berteknologi alat tangkap tradisional, karena secara kondisi ekonomi mereka tidak mampu membelinya. Biasanya nelayan kecil seperti ini disebut nelayan gurem, dimana mereka hidup secara subsisten hanya untuk pemenuhan kebutuhan pokok sehari-hari. Akan tetapi pada perkembangannya nelayan kecil juga mengkomersialkan hasil tangkapannya untuk dijual, dimanabiasanyamerekasetorkepadajuragan(boss).Hubungan nelayan kecil dengan juragannya memiliki ikatan patron-client 
yang sangat kuat. Hubungan nelayan dengan boss ini berdampak ketergantungan yang sangat tinggi. Secara tidak sadar kondisi tersebut malah mensengsarakan masyarakat.

Kondisi masyakat nelayan dapat juga dilihat pada aspek ekonomi. Kondisi ekonomi masyarakat nelayan selalu dipahami sebagai masyarakat yang memiliki ekonomi lemah. Seperti dikatakan oleh Bailey (1998) dikutip Muflikhati (2010), bahwa masyarakat nelayan miskin karena profesinya nelayan atau dikenal kemiskinan endemik, artinya apapun yang dikerjakan oleh nelayan, mereka tetap diartikan miskin. Hal ini berdasar pada pengartian kemiskinan yang berbeda di masyarakat sekitar. Menurut Bene (2003) dikutip Muflikhati (2010), kemiskinan nelayan dapat dibagi menjadi dua kelompok besar, yaitu yang menganut paradigma lama yang menyatakan bahwa kemiskinan nelayan terkait dengan sumber daya alam dan paradigma baru yang melihat kemiskinan nelayan dari berbagai sisi (multidimensi).Secara lebih rinci kondisi sosial-budaya nelayan dapat digambarkan sebagai berikut (Satria 2001; Satria 2009; Koentjaraningrat dalam Saad 2009; Mulyadi 2007; dan Numberi 2009):

1. Bentuk Hubungan sosial, yakni Hubungan patron klien yang kuat dengan juragan (Satria 2001) dan Identitas tempat sebagai unsur pengikat dan pembeda (Koentjaraningrat dalam Saad 2009)

2. Bentuk Oganisasi Kerja, yakni dilihat dari Terbatasnya SDM \& Lemahnya organisasi (Satria 2009). Selanjutnya juga dapat dilihat dari Nelayan buruh yang bekerja dengan alat tangkap milik orang lain, nelayan juragan yang memiliki alat tangkap dan dioperasikan orang lain, dan nelayan perorangan yang memiliki alat tangkap sendiri dan pengoperasian juga sendiri (Mulyadi 2007)

3. Bentuk Kerentanan Terhadap Bencana, yakni Masyarakat pesisir di pulau-pulau kecil Sangat rentan terhadap bencana (Numberi 2009)

Secara lebih rinci kondisi ekonomi nelayan pulau kecil dapat digambarkan dari bentuk-bentuknya sebagai berikut (Satria 2001; Satria 2009; Koentjaraningrat dalam Saad 2009; Mulyadi 2007; dan Numberi 2009) :

1. Bentuk Pemanfaatan Terhadap Sumberdaya laut, yakni Sangat bergantung pada kondisi sumberdaya alam khususnya Laut disekitarnya (Numberi 2009). Selanjutnya Sifat tangkapan yang open access membuat nelayan harus berpindah-pindah dan elemen risiko yang harus dihadapi lebih besar daripada petani darat (Pollnack dalam Satria 2001)

2. Bentuk Teknologi, yakni Melakukan modifikasi alat tangkap sesuai kondisi perairan (Sihombing 2003). Lebih lanjut Satria, 2009 mengemukakan bahwa nalayan pulau kecil memiliki teknologi dan permodalan yang lemah, sebagian besar masih menggunakan teknologi tradisional, Diversifikasi alat tangkap untuk mengantisipasi variasi musim.

3. Bentuk Permodalan, yakni Ikatan patron-client pada tengkulak, punggawa dan toke saat musim paceklik dalam permodalan sangat kuat (Satria 2009).

\section{Persepsi Nelayan terhadap Perubahan Iklim}

Menurut Baron dan Byrne (2004) persepsi adalah suatu proses memilih, mengorganisir, dan menginterpretasi informasi dikumpulkan oleh pengertian seseorang dengan maksud untuk memahami dunia sekitar. Sementara menurut Myers (2012) menyebutkan bahwa persepsi merupakan sebuah arahan seseorang untuk berperilaku. Persepsi dapat menjadi panduan atas tindakan berdasarkan makna yang diberikan pada stimulus yang dirasakan. Pengertian ini didasarkan pada saat terdapat suatu stimulus yang menarik perhatiannya, maka yang akan terjadi adalah suatu proses perceiving dan meaning. selain itu, terdapat pula interpretasi terhadap simbol-simbol yang ada pada stimulus tersebut. Proses persepsi tersebut dipengaruhi oleh konteks dimana individu tersebut berada.

Myers (2012) menyebutkan bahwa kemampuan persepsi seseorang dapat pula dipengaruhi oleh faktor lingkungan dan faktor internal. Faktor lingkungan terdiri intensitas terjadinya sebuah stimulus, ukuran sebuah stimulus, pengulangan stimulus yang sama, kemudahan untuk dicermati, gerakan yang diberikan oleh stimulus, serta keberadaan objek pada sebuah situasi. Sementara itu, yang dimaksud dengan faktor internal terdiri atas faktor fisiologis dan faktor psikologis. Faktor fisiologis adalah faktor-faktor yang didasari pada hasil penerimaan kelima indra manusia. Faktor psikologis dapat meliputi, motivasi, pengalaman, dan pengetahuan sebagai hasil pembelajaran di masa lalu.

Persepsi yang selektif dapat merupakan salah satu kunci dalammenentukan sikap serta perilaku. Persepsi memahami objek dan kemudian menginterpretasikannya menjadi sebuah perilaku. Pemaknaan suatu objek dapat bergantung pada perseptornya. Proses memahami lingkungan juga menjadi penting dalam upaya menentukan perilaku yang akan dilakukan olehnya. (Ross dan Nisbett 1991).

Dalam Borberg (2009) terdapat faktor-faktor yang membuat seseorang mau melakukan sebuah tindakan untuk beradaptasi terhadap perubahan iklim. Persepsi seseorang terhadap resiko yang diberikan perubahan iklim merupakan faktor yang berpengaruh terhadap tindakan yang dilakukan. Persepsi terhadap resiko yang dimiliki dapat terbentuk dari pengetahuan mereka seharihari dan pengalaman. Pengalaman dapat memengaruhi seorang nelayan untuk bertindak terhadap perubahan iklim. Jadi dapat disimpulkan, Persepsi nelayan terhadap perubahan iklim adalah kemampuan nelayan mengetahui tanda-tanda alam (angin, suhu, astronomi, biota, dan arus laut) karena terjadi perubahan dari kebiasaan seharihari. Persepsi dapat dilihat dari pengetahuan dari bentuk, dampak dan penyebab perubahan iklim.

\section{Adaptasi Perubahan Iklim}

Dalam mencegah terjadinya dampak yang luar biasa akibat perubahan iklim, maka diperlukan strategi preventif dan represif dalam pengendalian perubahan iklim. Strategi pengendalian dampak secara preventif dan represif adalah dengan melakukan adaptasi dan mitigasi. Adaptasi adalah respons terhadap stressor, berbeda dengan mitigasi yang melibatkan pre-empting tantangan dan mengambil langkah 
untuk menghindari ancaman seperti mengurangi emisi atau mengurangi dampak banjir dengan membangun tanggul (Scoones, 1998). Banyak dan beragam deskripsi tentang pemaknaan adaptasi dan mitigasi sendiri. Adaptasi menurut pemahaman tersebut lebih mengarah pada kegiatan represif, sedangkan mitigasi bisa dilakukan karena alasan preventif ataupun represif.

Menurut Murdiyarso (2005), adaptasi terhadap perubahan iklim adalah salah satu cara penyesuaian yang dilakukan secara spontan maupun terencana untuk memberikan reaksi terhadap perubahan iklim. Selanjutnya Smit dan Wandel (2006) menjelaskan bahwa adaptasi termasuk tindakan yang diambil untuk mengurangi kerentanan dan meningkatkan resiliensi, sedangkan kemampuan adaptasi adalah kemampuan untuk mengambil tindakan tersebut. Smit dan wandel (2006) juga melihat adaptasi pada aspek tindakan yang dilakukan serta seberapa besar kemampuan yang dilakukan dalam mengambil tindakan tersebut.

Konsep adaptasi yang dinyatakan oleh Mulyadi (2007) dikutip Helmi dan Satria (2012) adalah salah satu bagian dari proses evolusi kebudayaan, yakni proses yang mencakup rangkaian usaha-usaha manusia untuk menyesuaikan diri atau memberi respon terhadap perubahan lingkungan fisik maupun sosial yang terjadi secara temporal. Hal ini di dukung oleh pernyataan Bennet (1976) dan Pandey (1993) dikutip Helmi dan Satria (2012) yang memandang adaptasi sebagai suatu perilaku responsif manusia terhadap perubahan-perubahan lingkungan yang terjadi. Perilaku responsif tersebut memungkinkan mereka dapat menata sistem-sistem tertentu bagi tindakan atau tingkah lakunya, agar dapat menyesuaikan diri dengan situasi dan kondisi yang ada. Perilaku tersebut di atas berkaitan dengan kebutuhan hidup, setelah sebelumnya melewati keadaankeadaan tertentu dan kemudian membangun suatu strategi serta keputusan tertentu untuk menghadapi keadaankeadaan selanjutnya.

Berikut bentuk strategi adaptasi yang dilakukan oleh nelayan dalam menghadapi perubahan iklim (Priwardhani 2013; Helmi dan Satria 2012; Rochmayanto dan Kurniasih 2013), yaitu:

1. Dalam aspek ekonomi, disini muncul strategi pergeseran mata pencaharian dan divesifikasi mata pencaharian.

2. Dalam aspek teknik dan teknologi penangkapan, disini mucul strategi penganekaragaman alat tangkap dan strategi mengubah daerah penangkapan (fishing ground).

3. Dalam aspek sosial budaya, disini muncul strategi memanfaatkan hubungan sosial dan memobilisasi anggota keluarga.

\section{HASIL DAN PEMBAHASAN}

\section{Kondisi Geografis dan Kondisi Alam}

Desa Pulau Panjang merupakan salah satu desa administratif yang terletak di Kecamatan Subi, Kabupaten Natuna, Kepulauan Riau. Desa ini merupakan desa kecil dan terpencil yang terpisah sekitar 20 mil jaraknya dari pusat
Tabel 1 Jumlah Penduduk menurut Jenis Kelamin dan Golongan Usia

\begin{tabular}{cccc}
\hline Usia (tahun) & Laki-Laki & Perempuan & Jumlah \\
\hline $0-4$ & 32 & 22 & 54 \\
$5-9$ & 28 & 27 & 55 \\
$10-14$ & 20 & 21 & 41 \\
$15-19$ & 28 & 18 & 46 \\
$20-24$ & 24 & 21 & 45 \\
$25-29$ & 18 & 14 & 32 \\
$30-34$ & 15 & 16 & 31 \\
$35-39$ & 19 & 26 & 45 \\
$40-44$ & 27 & 26 & 48 \\
$45-49$ & 13 & 16 & 40 \\
$50-59$ & 13 & 12 & 25 \\
$60-64$ & 6 & 10 & 16 \\
$\geq 65$ & 8 & 9 & 27 \\
\hline Total & 266 & 245 & 511 \\
\hline Sumber: Data Kependudukan Desa Pulau Panjang, 2015
\end{tabular}

kecamatan. Waktu tempuh menuju Pusat Kecamatan dapat dilakukan hanya dengan menggunakan kapal motor dalam waktu tempuh sekitar tiga jam perjalanan. Sedangkan jarak Desa Pulau Panjang menuju pusat kantor pemerintahan kabupaten sekitar 80 mil dengan waktu tempuh 10 jam menggunakan kapal motor. Desa Pulau Panjang terdiri dari gugusan pulau-pulau kecil yang mengelilingi, yakni tiga pulau tidak berpenghuni (Pulau Jepu, Pulau Sebiang dan Pulau Mambat) dan satu pulau berpenghuni yakni Pulau Panjang yang menjadi pusat pemerintahan. Desa Pulau Panjang merupakan desa yang termasuk gugus pulau terluar bagian utara Indonesia dengan batas-batas wilayah sebagai berikut:

Sebelah Utara : Laut Kec. Subi

Sebelah Selatan : Desa Kerdau dan Laut Kec. Serasan Sebelah Barat : Laut Natuna

Sebelah Timur : Laut Malaysia - Serawak

Perjalanan menuju desa tersebut hanya dapat ditempuh dengan perjalanan laut. Luas wilayah desa ini adalah sekitar 503,67 Ha. Wilayah tersebut diperuntukan untuk perumahan, kebun, pekarangan dan mangrove. Ketinggian tanah diwilayah desa ini sekitar 0-5 meter diatas permukaan laut (dpl). Desa ini tidak terdapat bukit dan hanya berkontur datar daratannya. Kelembaban udara rata-rata adalah 85 persen dengan kelembaban udara maximal 99 persen dan minimal 55 persen. Temperatur udara rata-rata adalah $27^{\circ} \mathrm{C}$ dengan temperature maximal $35,6^{\circ} \mathrm{C}$ dan Minimal $18,9^{\circ} \mathrm{C}$. Kecepatan angin rata-rata wilayah Kabupaten Natuna khususnya Desa Pulau Panjang adalah 4 Knots dan maximal 34 Knots. Curah hujan Maximal 344 mm pada bulan November -Desemeber dan minimal $39.1 \mathrm{~mm}$ pada bulan Maret ${ }^{1}$.

1 Data BMKG-Stasiun Meteorologi Klas III Ranai, Natuna. 
Tabel 2 Matriks Kalender Musim yang Dianut Nelayan Pulau Panjang dalam Satu Tahun

\begin{tabular}{|c|c|c|c|c|c|c|c|c|c|c|c|c|}
\hline \multirow[t]{2}{*}{ Musim } & \multicolumn{12}{|c|}{ Bulan } \\
\hline & 1 & 2 & 3 & 4 & 5 & 6 & 7 & 8 & 9 & 10 & 11 & 12 \\
\hline Hujan & $* * *$ & $* *$ & $*$ & & & & & & $*$ & $* *$ & $* * *$ & $* * *$ \\
\hline Kemarau & & & & $*$ & $* *$ & $* * *$ & $* * *$ & $* *$ & $*$ & & & \\
\hline Gelombang Tinggi & $* * *$ & $* *$ & $* *$ & $*$ & $*$ & $*$ & $* *$ & $* * *$ & $* *$ & $* * *$ & $* * *$ & $* * *$ \\
\hline Angin Timur & & & $*$ & $*$ & $*$ & $*$ & & & & & & \\
\hline Angin Selatan & & & & & & & $* *$ & $* *$ & $* *$ & & & \\
\hline Angin Barat & & & & & & & & & & $* *$ & $* * *$ & \\
\hline Angin Utara & $* * *$ & $* * *$ & $* *$ & & & & & & & & & $* * *$ \\
\hline \multicolumn{13}{|l|}{ Hasil Tangkapan } \\
\hline Teripang & & & & $*$ & $* *$ & $* * *$ & $* *$ & $*$ & $*$ & & & \\
\hline Sunu & & & $* *$ & $* * *$ & $* * *$ & $* *$ & $*$ & $*$ & $*$ & & & \\
\hline Ketarap & & & $*$ & $* *$ & $* * *$ & $* * *$ & $* *$ & $*$ & $*$ & $*$ & & \\
\hline Kerapu & & $*$ & $*$ & $*$ & $*$ & $*$ & $*$ & $*$ & $*$ & $*$ & & \\
\hline Ikan Karang & $*$ & $*$ & $*$ & $*$ & $*$ & $*$ & $*$ & $*$ & $*$ & $*$ & $*$ & $*$ \\
\hline Tongkol & & & $*$ & $* * *$ & $* * *$ & $* *$ & $* *$ & $*$ & $*$ & & & \\
\hline Kepiting (Ketam) & & & & & $*$ & $* *$ & $* * *$ & $* *$ & $*$ & & & \\
\hline Cumi \& Sotong & & & $*$ & $* *$ & $* *$ & $* * *$ & $* *$ & $* *$ & $*$ & & & \\
\hline \multicolumn{13}{|l|}{ Alat Tangkap } \\
\hline Pancing & & & $* *$ & $* *$ & $* * *$ & $* * *$ & $* *$ & $* *$ & $* *$ & & & \\
\hline Pukat / Jaring & $*$ & $*$ & $*$ & $*$ & $*$ & $*$ & $*$ & $*$ & $*$ & $*$ & $*$ & $*$ \\
\hline Bubu & & & $* *$ & $* *$ & $* *$ & $* *$ & $* *$ & $* *$ & $* *$ & & & \\
\hline Tikam & & & $*$ & $*$ & $*$ & $*$ & $*$ & $*$ & $*$ & & & \\
\hline \multicolumn{13}{|c|}{ Kerja diluar Perikanan } \\
\hline Proyek Bangunan & $* * *$ & $* *$ & $*$ & & & & & & $*$ & $* *$ & $* * *$ & $* * *$ \\
\hline Kebun Kelapa & $*$ & $*$ & $* *$ & $* * *$ & $* *$ & $*$ & $* * *$ & $*$ & $* *$ & $* * *$ & $* *$ & $*$ \\
\hline Kebun Cengkeh & $* *$ & & & & & & & & & & $* *$ & $* * *$ \\
\hline
\end{tabular}

Sumber: Data Primer FGD Nelayan Pulau Panjang, 2015

Keterangan:

Intensitas rendah

Intensitas Sedang $* *$

Intensitas Tinggi $\quad * * *$

\section{Penduduk dan Mata Pencaharian}

Sejarah Desa Pulau Panjang dahulu adalah tempat persinggahan Datuk-Datuk Kaya dari Melayu. Dalam sejarah juga menyebutkan bahwa kabupaten Natuna dahulunya adalah tempat persinggahan jalur sutera. Terbukti dengan banyak ditemukannya benda-benda kramik bersejarah dari beberapa penjuru dunia di Pulau Panjang. Penduduk asli desa ini adalah keturunan melayu, tapi seiring perkembangan jaman juga muncul pendatang dari luar Pulau bahkan beberapa migran yang bertugas menjadi pemerintah desa, PNS dan guru. Total penduduk Desa Pulau Panjang berjumlah 148 KK dengan total 511 jiwa, secara lebih rinci laki-laki berjumlah 266 jiwa dan perempuan 245 jiwa. (Data Desa Pulau Panjang, 2015)

Berdasarkan data tersebut, dapat diketahui bahwa rasio beban tanggungan (dependency ratio) di Desa Pulau Panjang adalah 185,3. Artinya, dalam setiap 185 orang usia produktif menanggung 100 orang usia non-produktif. Sedangkan rasio jenis kelamin (sex ratio) 108 laki-laki per 100 perempuan. Sebagian besar penduduk bekerja sebagai nelayan atau pekerjaan yang masih berkaitan dengan hasilhasil laut. Selebihnya, merupakan petani kebun (kelapa dan cengkeh), pedagang dan buruh bangunan.

\section{Kondisi Ekonomi Perikanan Pulau Panjang}

Kondisi perikanan di Pulau Panjang rata nelayan bekerja efektif pada musim angin timur dimana intensitas angin rendah sampai musim angin selatan dimana kondisi angin sedang. Pada musim angin barat nelayan mengikuti kondisi pagi hari, karena dirasa pada musim angin barat adalah peralihan intensitas angin sedang ke musim angin utara. Pada musim angin utara intensitas angin dan badai dilaut sangat tinggi. Karena kondisi nelayan disana adalah nelayan kecil dengan kapasitas kapal mesin 0,5- 3 GT, 
Tabel 3 Jumlah dan Persentase Responden Berdasarkan Usia

\begin{tabular}{lrc}
\hline \multicolumn{1}{c}{ Usia } & n & Responden \\
\hline Muda (18-30 tahun) & 4 & 13,3 \\
Dewasa (31-50 tahun) & 22 & 73,3 \\
Tua (>50 tahun) & 4 & 13,3 \\
Total & 30 & 100,0 \\
\hline
\end{tabular}

pada musim angina utara nelayan tidak ada yang berani melaut. Secara lebih rinci musim yang dianut nelayan dapat dilihat pada Tabel 3.

Kondisi tangkapan mereka antara lain di musim timur ikan dirasa melimpah ruah. Ikan kerapu macan, sunu dan ketarap walau hanya dengan pompong kecil, mereka berangkat sekali trip dapat membawa pulang 4-5 ekor ikan sunu dan ketarap dengan pancing ulur dengan harga jual per ekor Rp. 50.000,00/ekor untuk ukuran kecil (panjang $10 \mathrm{~cm}$ ), Rp. 70.000,00 - Rp. 80.000,00/ekor (panjang 15 $\mathrm{cm}$ ) untuk ukuran sedang, dan Rp 120.000,00/ekor untuk ukuran super (20-30 cm lebih). Untuk mendapatkan ukuran super mereka harus membesarkan ikan lagi pada keramba ikan (waring). Jenis ikan kerapu tiger untuk ukuran kecil dapat mencapai harga Rp. 80.000,00/ekor, sedang untuk ukuran sedang dihargai Rp. 100.000,00/ ekor dan ukuran super dihagai Rp. 240.000,00/ekor.

Selain mendapatkan jenis ikan mahal diatas, nelayan juga dapat mendapatkan jenis ikan Tongkol (ikan harga sedang) dengan pancing ulur dari bulan April - September, sedang puncaknya berada pada bulan April-Mei. Sekali trip di bulan puncak mereka dapat mendapatkan ikan 1025 ekor, dengan harga Rp. 20.000 - Rp 30.000 / ekor. Hanya dengan modal berjalan kaki dan menyusuri pantai menggunakan alat tikam / singkap atau tombak pada bulan April-September, nelayan biasanya mendapatkan ketam atau kepiting pada malam hari. Proses menangkap ketam, nelayanhanya perlu berjalan kaki selama minimal satu sampai dua jam ketika bulan puncak. Tangkapan nelayan permalam rata-rata dapat menangkap 5-10 kg ketam dengan harga jual Rp. 10.000,00 / kg. Selain ketam, dengan cara penangkapan yang sama di bulan Maret-September nelayan dapat mendapatkan tangkapan cumi-cumi dan sotong. Pada bulan puncak nelayan bisa mendapatkan 3 $4 \mathrm{~kg}$ dengan harga jual Rp. 12.000,00 / kg cumi dan sotong

Tabel 5 Jumlah dan Persentase Responden berdasarkan Tingkat Pendidikan

\begin{tabular}{lcc}
\hline \multicolumn{1}{c}{ Tingkat Pendidikan } & \multicolumn{2}{c}{$\begin{array}{c}\text { Responden } \\
\text { n }\end{array}$} \\
\hline $\begin{array}{l}\text { Rendah } \\
\text { (Tidak Sekolah atau Tamat SD Sederajat) }\end{array}$ & 24 & 80,0 \\
$\begin{array}{l}\text { Sedang } \\
\text { (Tamat SMP/Sederajat) }\end{array}$ & 6 & 20,0 \\
$\begin{array}{l}\text { Tinggi } \\
\text { (Tamat SMA/Sederajat atau Perguruan }\end{array}$ & 0 & 00,0 \\
$\begin{array}{l}\text { Tinggi) } \\
\text { Total }\end{array}$ & 30 & 100,0 \\
\hline
\end{tabular}

Tabel 6 Jumlah dan Persentase Responden Berdasarkan Tingkat Lama Bekerja Nelayan

\begin{tabular}{lll}
\hline \multicolumn{1}{c}{ Lama Bekerja Nelayan } & \multicolumn{2}{c}{ Responden } \\
& $\mathbf{n}$ & $\mathbf{\%}$ \\
\hline Rendah (0-10 tahun) & 2 & 6,7 \\
Sedang (11-20 tahun) & 10 & 33,3 \\
Tinggi ( $\geq 21$ tahun) & 18 & 60,0 \\
Total & 30 & 100,0 \\
\hline
\end{tabular}

dengan bermodalkan alat tikam serta berjalanan kaki di bibir pantai ketika air pasang.

Kondisi geografis pantai Pulau Panjang di kelilingi karang yang luas, sehingga pada bulan April sampai Agustus nelayan dapat mendapatkan bonus geografis yakni tangkapan teripang. Pada bulan puncak di bulan MeiJuni, semalam berjalan menyusuri pantai nelayan dapat mendapatkan tangkapan 1-2 kg teripang. Apabila teripang telah di keringkan harga jual adalah Rp. 400.000,00 - Rp. $600.000,00 / \mathrm{kg}$. Bulan-bulan musim teripang ini dirasa bulan -bulan paling menguntungkan bagi nelayan. Kondisi ikan yang paling stabil pada setiap bulannya adalah jenis ikan karang, ikan jenis ini tidak banyak jumlahnya tapi hasil tangkapan nelayan rata-rata tetap jumlahnya pada setiap bulan. Harga jual per kilogram ikan karang atau nelayan menyebutnya ikan biasa adalah Rp 5000,00 $8000,00 / \mathrm{kg}$.

Tabel 2 memperlihatkan musim pada saat nelayan melakukan kerja diluar sektor perikanan khususnya pada musim utara. Pekerjaan tambahan seperti proyek bangunan lebih banyak pada bulan-bulan September sampai Maret. Hal ini terjadi karena pada bulan-bulan tersebut sedang terjadi musim utara dengan peningkatan intensitas badai yang tinggi di laut. Pada musim utara tidak ada nelayan yang berani melaut, karena kondisi kapal mereka sebagian besar adalah kapal atau pompong kecil. Nelayan menyiasati musim utara dengan upaya bergantian mengerjakan proyek bangunan infrastrutur dari pemerintah desa. Proses pergantiannya adalah perRT akan mendapat jatah untuk mengerjakan proyek dalam waktu 1 minggu sesuai jumlah tenaga kerja yang di butuhkan dari kontraktor.

Pekerjaan lainnya adalah kerja kebun kelapa dan kebun cengkeh, nelayan merasa untuk menunjang pengeluaran kebutuhan mereka harus melakukan penganekaragaman pekerjaan. Pekerjaan kebun kelapa dan cengkeh adalah salah satu penunjang ekonomi masyarakat Pulau Panjang.

Tabel 7 Jumlah dan Persentase Responden Berdasarkan Jumlah Anggota Rumah Tangga

\begin{tabular}{lll}
\hline \multirow{2}{*}{ Jumlah Anggota Rumah Tangga } & \multicolumn{2}{c}{ Responden } \\
& n & \% \\
\hline Rendah (1-3 orang) & 6 & 20,0 \\
Sedang (4-6 orang) & 23 & 76,7 \\
Tinggi ( $\geq 7$ ) & 1 & 3,3 \\
Total & 30 & 100,0 \\
\hline
\end{tabular}


Tabel 8 Perubahan Kalender Musim Tangkap Ikan Sebelum dan Sesudah Tahun 2000, pada Komunitas Nelayan Pulau Panjang

\begin{tabular}{|c|c|c|c|c|c|c|c|c|c|c|c|c|}
\hline \multirow{2}{*}{ Musim Tangkap } & \multicolumn{12}{|c|}{ Bulan } \\
\hline & 1 & 2 & 3 & 4 & 5 & 6 & 7 & 8 & 9 & 10 & 11 & 12 \\
\hline Puncak (Dulu) & & & $*$ & $*$ & $*$ & $*$ & & & & & & \\
\hline Puncak (Sekarang) & & & & $*$ & $*$ & & & & & & & \\
\hline Normal (Dulu) & & $*$ & * & $*$ & $*$ & * & $*$ & & & & & \\
\hline Normal (Sekarang) & & & * & $*$ & $*$ & $*$ & & & & & & \\
\hline Sulit Ikan (Dulu) & $*$ & & & & & & & $*$ & * & & & \\
\hline Sulit Ikan (Sekarang) & $*$ & $*$ & & & $*$ & $*$ & $*$ & $*$ & $*$ & & & \\
\hline
\end{tabular}

Sumber: Data Primer FGD Nelayan Pulau Panjang, 2015

Keterangan:

Intensitas rendah

Intensitas Sedang

Intensitas Tinggi

Pekerjaan kebun kelapa dan cengkeh akan menjadi fokus pekerjaan nelayan apabila terjadi musim utara, apabila musim lautan sedang teduh yakni pada bulan maret hingga juni makan nelayan lebih banyak fokus pada pekerjaan di laut. Karena pekerjaan di sektor laut lebih menjanjikan daripada menggarap lahan kebun mereka yang luasnya tidak seberapa atau mengelilingi rumah mereka sebagai pekarangan.

Kondisi geografis rumah masyarakat Pulau Panjang rata-rata memiliki halaman yang luas dan jarak antar rumah ke rumah terpisah-pisah atau tidak sejajar seperti di perkotaan. Halaman tersebut ditanami tanaman kelapa oleh masyarakat. Minimal masyarakat memiliki 20-30 batang kelapa yang mengelilingi rumahnya. Dalam satu tahun masyarakat dapat melakukan pemanenan 3-4 kali atau tiga bulan sekali. Kelapa ini setelah di panen akan diambil kopranya dan disalai (di panggang dengan asap serabut dan batok kelapa kering). Hasil panggangan kopra ini masyarakat menyebutnya niok. Harga jual niok ini per kilogram Rp 4.800,00 sampai Rp 6.000,00. Dalam satu pohon dapat menghasilkan niok kurang lebih 3-5 kilogram. Sistem sosial ekonomi kerja kelapa adalah biasanya pemilik kebun (nelayan yang memiliki kebun) bagi hasil sesuai kesepakatan dengan penggarap (biasanya nelayan yang tidak memiliki lahan dan kebun melakukan pemanenan sampai menjadi menjadi niok).

Selain melakukan pemanenan kebun kelapa nelayan juga melakukan kerja cengkeh. Tanaman cengkeh ini adalah tanaman tahunan yang dipanen setiap 3-4 tahun sekali. Kondisi sosial ekonomi nelayan melakukan pekerjaan ini sama dengan sistem kerja kelapa, yaitu nelayan yang memiliki kebun cengkih biasanya melakukan bagi hasil dengan penggarap (nelayan yang melakukan pemanenan atau disebut panjat cengkeh). Harga jual cengkeh per kilogram adalah Rp 100.000, 00. Pekerjaan kebun akan dikerjakan secara maksimal oleh nelayan ketika tiba musim utara.

Tingkat Pendapatan Rumah Tangga Nelayan Desa Pulau Panjang dapat dilihat pada Gambar 2. Tingkat pendapatan nelayan dikategorikan kedalam tiga golongan yaitu rendah, sedang, dan tinggi. Tingkat pendapatan rendah terdiri dari nelayan dengan pendapatan dibawah $\mathrm{Rp}$. 2000.000,00. Tingkat pendapatan sedang terdiri dari nelayan dengan selang pendapatan antara Rp.2000.000,00 - Rp. 3000.000,00. Sedangkan untuk tingkat pendapatan tinggi adalah nelayan dengan jumlah pendapatan lebih dari Rp.3000.000,00. Pada Gambar 2 terlihat bahwa pendapatan masyarakat nelayan di Desa Pulau Panjang yang cenderung tinggi. Pendapatan rumah tangga ini bersumber dari pekerjaaan pada perikanan tangkap, dan pekerjaan diluar perikanan tangkap yang dilakukan nelayan serta pemasukan dari anggota keluarga lainnya (istri).

\section{Karakteristik Responden}

\section{Usia Responden}

Usia adalah rentang tahun responden dilahirkan hingga tahun pada saat dilaksanakan penelitian. Jumlah dan persentase responden berdasar usia dapat dilihat pada Tabel 3.

Usia responden bervariasi, terendah mulai dari 25 tahun dan tertinggi 54 tahun. Data pada Tabel 6 memperlihatkan bahwa usia rata-rata responden adalah 39 tahun dari total 30 responden. Responden yang berusia muda berjumlah 4 orang atau sekitar 13,3 persen, dewasa berjumlah 22 orang atau sekitar 73,3 persen, dan tua berjumlah 4 orang atau sekitar 13,3 persen. Kesimpulannya adalah sebagian besar responden nelayan di Desa Pulau Panjang lebih banyak berusia dewasa daripada kategori usia muda dan tua.

\section{Pendidikan Responden}

Pendidikan responden adalah jenjang tertinggi dari pendidikan yang pernah ditempuh oleh responden. Jumlah dan persentase tingkat pendidikan responden dapat dilihat pada Tabel 4. Pada tabel tersebut terlihat sebaran yang tidak merata karena memang kondisi nelayan di Desa Pulau 
Tabel 9 Perubahan Kalender Musim Hujan dan Angin Sebelum dan Sesudah Tahun 2000, pada Komunitas Nelayan Pulau Panjang

\begin{tabular}{|c|c|c|c|c|c|c|c|c|c|c|c|c|}
\hline \multirow{2}{*}{ Musim } & \multicolumn{12}{|c|}{ Bulan } \\
\hline & 1 & 2 & 3 & 4 & 5 & 6 & 7 & 8 & 9 & 10 & 11 & 12 \\
\hline Hujan (Dulu) & $*$ & $*$ & $*$ & & & & & $*$ & $*$ & $*$ & $*$ & \\
\hline Hujan (Sekarang) & $*$ & * & $*$ & $*$ & & & & & $*$ & $*$ & $*$ & \\
\hline Kemarau (Dulu) & & & & $*$ & $*$ & $*$ & $*$ & $*$ & $*$ & & & \\
\hline Kemarau (Sekarang) & & & & * & $*$ & $*$ & $*$ & $*$ & $*$ & $*$ & & \\
\hline Angin Timur (Dulu) & & & $*$ & $*$ & $*$ & $*$ & & & & & & \\
\hline Angin Timur (Sekarang) & & & $*$ & $*$ & $*$ & & & & & & & \\
\hline Angin Selatan (Dulu) & & & & & & $*$ & $*$ & $*$ & & & & \\
\hline Angin Selatan (Sekarang) & & & & & $*$ & $*$ & $*$ & & & & & \\
\hline Angin Barat (Dulu) & & & & & & & & & $*$ & $*$ & & \\
\hline Angin Barat (Sekarang) & & & & & & & & $*$ & $*$ & $*$ & & \\
\hline Angin Utara (Dulu) & $*$ & $*$ & & & & & & & & & $*$ & \\
\hline Angin Utara (Sekarang) & $*$ & $*$ & $*$ & & & & & & & $*$ & $*$ & \\
\hline
\end{tabular}

Sumber: Data Primer FGD Nelayan Pulau Panjang, 2015

Keterangan:

Intensitas rendah

Intensitas Sedang

Intensitas Tinggi

Panjang yang berpendidikan maksimal hanya sampai SMP dan tidak ada yang SMA bahkan sampai perguruan tinggi.

Responden yang berpendidikan kategori rendah berjumlah 24 orang atau 80 persen, kategori sedang berjumlah 6 orang atau 20 persen, dan tidak ada yang berpendidikan tinggi. Kesimpulan yang dapat diambil adalah rata-rata responden nelayan di Desa Pulau Panjang banyak yang berkategori tingkat pendidikannya rendah dan nihil untuk kategori responden berpendidikan tinggi.

\section{Lama Bekerja Nelayan}

Lama bekerja nelayan adalah rentang waktu dalam awal tahun lamanya responden bekerja sebagai nelayan sampai penelitian dilakukan. Jumlah dan persentase tingkat lama responden bekerja sebagai nelayan dapat dilihat pada Tabel 5.

Responden yang berkategori rendah 2 orang atau 6,7 persen, sedang 10 orang atau 33,3 persen dan tinggi 18 orang atau 60 persen dengan total responden berjumlah 30 orang. Kesimpulan yang dapat diambil yaitu sebagian besar responden telah berkategori lama dalam bekerja nelayan yaitu diatas 20 tahun.

\section{Jumlah Anggota Rumah Tangga}

Jumlah anggota rumah tangga adalah banyaknya orang yang menetap dalam satu rumah tempat tinggal nelayan. Jumlah dan persentase anggota rumah tangga responden dapat dilihat pada Tabel 6 .

Responden yang memiliki kategori rendah berjumlah 6 orang atau sekitar 20 persen, sedang berjumlah 4-6 orang atau sekitar 76,7 persen, dan tinggi berjumlah 1 orang atau sekitar 3,3 persen dengan total responden berjumlah 30 orang. Kesimpulan yang dapat diambil yaitu rata-rata jumlah anggota para responden berukuran sedang atau sekitar 4-6 orang.

\section{Perubahan Iklim dan Pengaruhnya terhadap Kondisi Ekologi dan Sosial-Ekonomi Nelayan}

\section{Pengaruh Perubahan Iklim Pada Aspek Sosial-Ekonomi}

Perubahan iklim yang terjadi juga berdampak pada kondisi sosial, budaya dan ekonomi nelayan. Indikator dan Dampak-dampak perubahan iklim terhadap sosial, budaya dan ekonomi nelayan sebagai berikut (Surtiari 2011; Priwardhani 2013; dan Diposaptono et.al 2009):

1. Perubahan pola musim (bergesernya waktu dimulai dan berakhirnya musim) dan pola angin yang dianut nelayan menyebabkan nelayan sulit memperkirakan kondisi laut, menggangu kegiatan kenelayanan dan keselamatan nelayan. Untuk memahami perubahan iklim secara historis baik laju dan dampak perubahan iklim yang terjadi di Pulau Panjang pada kondisi sosial ekonominya. Pada Tabel 7 terlihat data perubahan kalender musim tangkap yang dianut nelayan.

Data pada Tabel 7 bersumber dari data primer FGD dengan nelayan Pulau Panjang. Data tersebut memperlihatkan perubahan pola musim (bergesernya waktu dimulai dan berakhirnya musim), terjadi perubahan puncak musim tangkapan ikan dulu dibawah tahun 2000 terlihat puncak banyaknya ikan berada pada bulan Maret hingga 
Tabel 10 Hubungan Usia Responden dengan Persepsi Nelayan terhadap Perubahan Iklim

\begin{tabular}{clcc}
\hline & Usia & $\begin{array}{c}\text { Persepsi } \\
\text { terhadap } \\
\text { Perubahan } \\
\text { Iklim }\end{array}$ \\
\hline Usia & Correlation & 1.000 & -.360 \\
& $\begin{array}{c}\text { Coefficient } \\
\text { Sig. (2-tailed) }\end{array}$ & .05 & .051 \\
Persepsi & $\mathrm{N}$ & 30 & 30 \\
$\begin{array}{c}\text { terhadap } \\
\text { Perubahan } \\
\text { Iklim }\end{array}$ & Correlation & -.360 & 1.000 \\
& Coefficient & & \\
& Sig. (2-tailed) & .051 &. \\
& $\mathrm{~N}$ & 30 & 30 \\
\hline
\end{tabular}

Juni. Nelayan merasa pada bulan-bulan tersebut ikan melimpah. Sedangkan sekarang (diatas tahun 2000an) nelayan merasakan puncak tangkapan hanya pada bulan April - Mei saja. Waktu normal nelayan menangkap ikan dahulu adalah dari Februari - Oktober. Sedangkan sekarang nelayan hanya dapat bekerja normal pada bulan Maret - Agustus. Waktu Sulit ikan biasanya jatuh pada musim utara, yaitu pada kondisi angin kencang. Dahulu nelayan merasa sulit mencari ikan pada bulan November - Januari, tapi sekarang pada bulan Agustus - Februari nelayan mulai merasa tangkapan sulit bahkan sedikit karena pengaruh cuaca. Disini terjadi musim sulit ikan yang berkepanjangan atau kondisi waktu yang tidak menentu.

Komunitas nelayan di Kabupaten Natuna, pada umumnya menggunakan prediksi musim angin untuk melakukan aktivitas penangkapan di laut. Selain musim hujan dan kemarau, komunitas nelayan di Natuna khususnya desa Pulau Panjang mengenal pola musim angin timur, angin selatan, angin barat, dan angin utara. Pola musim yang dianut nelayan ini menjadi hal penting yang sangat diperhatikan nelayan dalam bekerja di laut. Musim angin timur adalah musim dengan kondisi gelombang laut yang dirasa teduh (tenang), intensitas ombak sedikit, dan pada

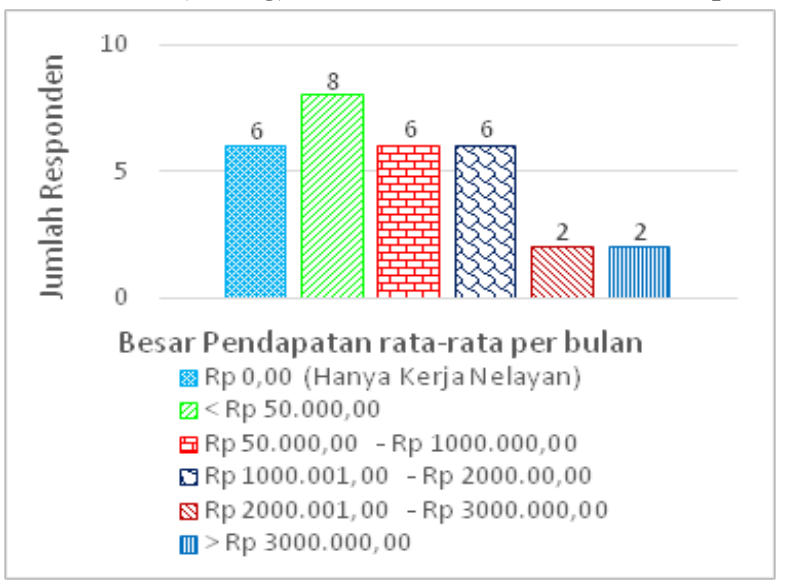

Gambar 3 Diagram Tingkat Pendapatan Nelayan Desa Pulau Panjang Bersumber dari Sektor Perikanan Tangkap
Tabel 11 Hubungan Tingkat Pendidikan dengan Persepsi Nelayan terhadap Perubahan Iklim

\begin{tabular}{|c|c|c|c|}
\hline & & $\begin{array}{c}\text { Tingkat } \\
\text { Pendidikan }\end{array}$ & $\begin{array}{c}\text { Persepsi } \\
\text { terhadap } \\
\text { Perubahan } \\
\text { Iklim } \\
\end{array}$ \\
\hline \multirow[t]{3}{*}{$\begin{array}{c}\text { Tingkat } \\
\text { Pendidikan }\end{array}$} & $\begin{array}{l}\text { Correlation } \\
\text { Coefficient }\end{array}$ & 1.000 & $-.371^{*}$ \\
\hline & $\begin{array}{l}\text { Sig. } \\
\text { (2-tailed) }\end{array}$ & $a_{0}$ & .043 \\
\hline & $\mathrm{N}$ & 30 & 30 \\
\hline \multirow{3}{*}{$\begin{array}{c}\text { Persepsi } \\
\text { terhadap } \\
\text { Perubahan } \\
\text { Iklim }\end{array}$} & $\begin{array}{l}\text { Correlation } \\
\text { Coefficient }\end{array}$ & $-.371^{*}$ & 1.000 \\
\hline & $\begin{array}{l}\text { Sig. } \\
\text { (2-tailed) }\end{array}$ & .043 & $\cdot$ \\
\hline & $\mathrm{N}$ & 30 & 30 \\
\hline
\end{tabular}

musim ini dirasa hasil tangkapan ikan mulai meningkat untuk beberapa komoditi tangkapan seperti ikan Sunu, Ketarap dan Kurisi. Nelayan beranggapan bahwa pada awal musim timur beberapa jenis ikan seperti napoleon mulai bertelur. Setelah musim angin timur, selanjutnya masuk pada musim selatan. Pada musim selatan, nelayan merasa bahwa hasil ikan berada pada titik maksimum atau musim puncak hasil tangkapan (Ikan Sunu, Ketarap, dan Kurisi). Musim selatan menjadi musim yang membawa keberuntungan lebih bagi nelayan, karena selain hasil tangkapan ikan maksimal pada musim ini nelayan dapat menangkap Teripang dan jenis ikan tongkol mulai bermunculan. Teripang adalah jenis hewan laut dengan harga jual tinggi. Hal ini di dukung dengan pernyataan salah seorang nelayan pada saat FGD, Bapak YSP (50 th): “... Dahulu musim angin dan badai bisa ditebak jatuh pada bulan sebelas, dua belas dan satu. Tapi sekarang di bulan-bulan tuju, delapan sampai bulan tiga angin kencang dan badai tiba-tiba muncul. Sulit ditebak sekarang untuk mendapat banyak ikan dan musim anginnya... ... Hal ini mulai terasa di atas tahun 2000-an sampai sekarang mas..."

2. Hilangnya beberapa hewan yang menjadi

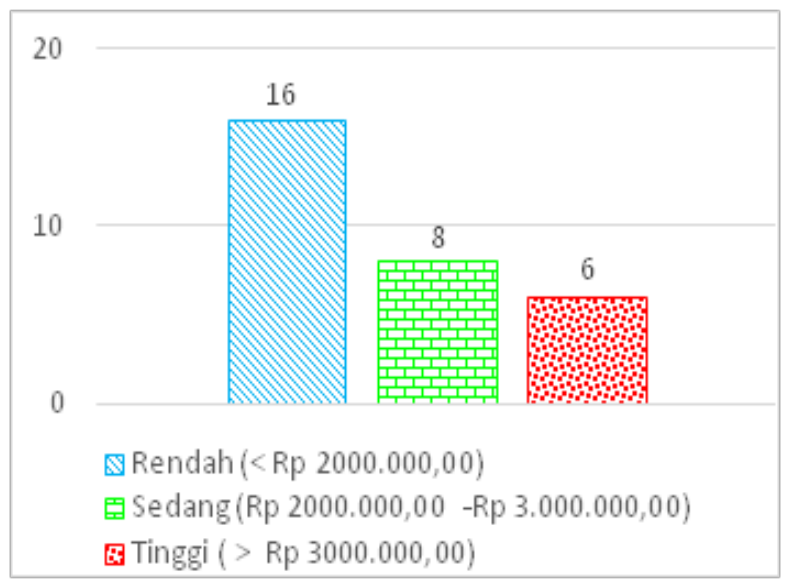

Gambar 4 Diagram Besaran Pendapatan Nelayan yang Bersumber dari Non Perikanan 
Tabel 12 Hubungan Lama Bekerja Nelayan dengan Persepsi Nelayan terhadap Perubahan Iklim

\begin{tabular}{|c|c|c|c|}
\hline & & $\begin{array}{c}\text { Lama } \\
\text { Bekerja } \\
\text { Nelayan }\end{array}$ & $\begin{array}{c}\text { Persepsi } \\
\text { terhadap } \\
\text { Perubahan } \\
\text { Iklim }\end{array}$ \\
\hline \multirow{2}{*}{$\begin{array}{l}\text { Lama } \\
\text { Bekerja } \\
\text { Nelayan }\end{array}$} & $\begin{array}{l}\text { Correlation } \\
\text { Coefficient }\end{array}$ & 1.000 & -.149 \\
\hline & $\begin{array}{l}\text { Sig. } \\
\text { (2-tailed) }\end{array}$ & & .432 \\
\hline \multirow{4}{*}{$\begin{array}{l}\text { Persepsi } \\
\text { terhadap } \\
\text { Perubahan } \\
\text { Iklim }\end{array}$} & $\begin{array}{l}\mathrm{N} \\
\text { Correlation }\end{array}$ & 30 & 30 \\
\hline & Coefficient & -.149 & 1.000 \\
\hline & $\begin{array}{l}\text { Sig. } \\
\text { (2-tailed) }\end{array}$ & 432 & . \\
\hline & & 30 & 30 \\
\hline
\end{tabular}

penanda pergantian musim. Nelayan di Desa Pulau Panjang dalam menentukan musim juga dibantu oleh tanda-tanda alam melalui hewan. Menurut nelayan pada jaman dahulu setiap pergantian musim barat ke utara nelayan melihat sekerumunan burung Piling yang terbang berkelompok di atas desa pulau panjang. Burung piling menurut para nelayan adalah jenis burung migrasiberwarna putih, burung tersebut hanya muncul ketika akan masuk musim utara. Beberapa tahun terakhir ini masyarakat merasa keberadaan burung Piling sudah jarang dilihat atau menghilang keberadaannya. Selain penanda burung Piling, pada pergantian musim utara ke timur atau menjelang musim teduh, nelayan terkadang mendengar kicauan burung Kake (Dendang Laut). Burung ini berwarna hitam yang terbang di sekeliling desa. Keberadaan burung Kake saat ini sudah tidak diketemukan keberadaan dan suara kicauannya tidak terdengar lagi oleh warga Desa Pulau Panjang. Masyarakat merasa keberadaan kedua burung ini sangat membantu mereka dalam memprediksi bergantinya musim.

3. Pengaruh pada tingkat pendapatan dari sektor tangkapan nelayan. Perubahan iklim yang terjadi sampai sekarang ini dirasa masyarakat sangan mempengaruhi pendapatan mereka dalam sektor perikanan tangkap. Masyarakat merasa bahwa pendapatan mereka semenjak terjadinya perubahan iklim yang perubahannya sangat terasa dari tahun 2000 sampai sekarang, membuat hasil pendapatan mereka menurun. Tingkat pendapatan pada sektor perikanan tangkap nelayan Desa Pulau Panjang dapat dilihat pada Gambar 3.

Pada Gambar 3 tersebut terlihat rata-rata pendapatan nelayan yang cenderung rendah atau $<$ Rp. 2000.000,00 pada sektor perikanan tangkap nelayan. Hal ini terjadi karena dampak perubahan iklim yang berpengaruh pada perubahan ekologi wilayah penangkapan nelayan. Pernyataan ini juga di dukung data kualitatif yang direduksi dari pernyataan para nelayan yang diwakili pernyataan dari Bapak SMN (39 th), Ketua Kelompok Nelayan:

“...Dulu mencari ikan tuh gampang bang, hanya pakai dayung lepas dari ujung pantai kita bisa dapat banyak
Tabel 13 Hubungan Jumlah Anggota Rumah Tangga Nelayan denganPersepsi Nelayan terhadap Perubahan Iklim

\begin{tabular}{llcc}
\hline & & $\begin{array}{c}\text { Jumlah } \\
\text { Anggota } \\
\text { Rumah } \\
\text { Tangga }\end{array}$ & $\begin{array}{c}\text { Persepsi } \\
\text { terhadap } \\
\text { Perubahan } \\
\text { Iklim }\end{array}$ \\
\hline Jumlah & Correlation & 1.000 & -.073 \\
Anggota & Coefficient \\
Rumah & Sig. (2-tailed) &. & .702 \\
Tangga & $\mathrm{N}$ & 30 & 30 \\
$\begin{array}{l}\text { Persepsi } \\
\text { terhadap }\end{array}$ & Correlation & & \\
$\begin{array}{l}\text { Perubahan } \\
\text { Iklim }\end{array}$ & & -.073 & 1.000 \\
& Sig. (2-tailed) & .702 & \\
& $\mathrm{~N}$ & 30 &. \\
\hline
\end{tabular}

ikan dan ikan-ikan besar itupun pakai pancing. Tapi sekarang sejak cuaca yang tak tentu, kondisi karang yang rusak juga, walau pakai pancing kita dapat ikan Cuma sedikit. Kita tak bisa hanya bergantung pada tangkap ikan dilaut dengan cara lama atau pancing saja untuk mencukupi periuk keluarga. Rata-rata nelayan disini juga punya kerja sambilan selain hanya kerja nelayan...”.

Pendapatan nelayanjikahanyabersumberpada penangkapan ikan saja maka akan cenderung terlihat pendapatan per kapita yang rendah. Nelayan dalam menyikapi pengaruh perubahan iklim yang terjadi dan kondisi ikan tidak menentu, mereka menyiasatinya dengan melakukan kerja tambahan diluar sektor perikanan. Berikut diagram besaran tambahan pendapatan nelayan yang bersumber dari non perikanan dapat dilihat pada Gambar 4.

Pada Gambar 4 terlihat bahwa nelayan yang melakukan diversifikasi kegiatan ekonomi dengan bekerja diluar sektor perikanan tangkap seperti kebun kelapa, cengkeh, dan tukang. Mereka cenderung akan mendapatkan penghasilan tambahan antara Rp. 50.000,00 sampai bahkan diatas Rp. 3.000.000,00. Sedangkan nelayan yang hanya bekerja sebagai nelayan saja mereka terlihat tidak mendapatkan penghasilan tambahan atau sebesar Rp 0,00.

\section{Indikator Perubahan Iklim pada Aspek Ekologi}

Perubahan iklim global mengakibatkan kerugian yang sangat besar di tingkat lokal. Perubahan iklim berimbas pada segala sector khususnya wilayah pesisir. Masyarakat yang paling rentan dalam perubahan iklim adalah masyarakat wilayah pesisir dan pulau-pulau kecil (Diposaptono et.al 2009 dan Satria 2009). Indonesia memiliki 17.480 pulau dan 65 persen pulau-pulau yang ada di Indonesia merupakan pulau-pulau kecil yang sangat rentan terhadap dampak perubahan iklim. Hingga saat ini telah tercatat sebanyak 24 pulau-pulau kecil di Indonesia hilang disebabkan oleh tsunami, abrasi dan kegiatan pertambangan pasir yang tidak 
Tabel 14 Jenis Alat Tangkap dan Jenis Tangkapan Nelayan

\begin{tabular}{|c|c|c|}
\hline \multicolumn{2}{|c|}{ Jenis Alat Tangkap } & \multirow{2}{*}{\begin{tabular}{l}
\multicolumn{1}{c}{ Jenis Tangkapan } \\
Kakap, Kerapu, \\
Simbok (Tongkol), \\
Pari, Sunu, Ketarap, \\
Ikan karang
\end{tabular}} \\
\hline $\begin{array}{l}\text { Pancing } \\
\text { Ulur }\end{array}$ & $\begin{array}{l}\text { Kail no. } 7 \text { dan } \\
\text { Senar no. } 500\end{array}$ & \\
\hline & $\begin{array}{l}\text { Kail no. } 8-9 \\
\text { dan senar no. } \\
200\end{array}$ & Layur, Kalat, tenggiri \\
\hline & $\begin{array}{l}\text { Kail 13-12 dan } \\
\text { senar } 60-70\end{array}$ & Ketambak \\
\hline Bubu & $\begin{array}{l}\text { Lubang jaring } \\
1 \text { inci dan } \\
\text { ukuran luas } \\
3 \mathrm{~m}^{2}\end{array}$ & $\begin{array}{l}\text { Kerapu (macan), ikan } \\
\text { karang }\end{array}$ \\
\hline \multirow[t]{2}{*}{$\begin{array}{l}\text { Jaring } \\
\text { (pukat) }\end{array}$} & $\begin{array}{l}\text { Mata Jaring } \\
\text { berukuran } 2 \\
\text { inci }\end{array}$ & Ikan Karang \\
\hline & $\begin{array}{l}\text { Mata Jaring } \\
\text { berukuran 4-6 } \\
\text { inci }\end{array}$ & $\begin{array}{l}\text { Layur Ikan berukuan } \\
\text { besar }\end{array}$ \\
\hline $\begin{array}{l}\text { Tikam / } \\
\text { Tombak }\end{array}$ & & $\begin{array}{l}\text { Cumi - Cumi, Sotong, } \\
\text { Pari, Pangsik (Kerang } \\
\text { karang) }\end{array}$ \\
\hline $\begin{array}{l}\text { Alat } \\
\text { Selam dan } \\
\text { Kompresor }\end{array}$ & & $\begin{array}{l}\text { Ikan di kedalaman laut } \\
\text { (Kurisi, Napoleon, } \\
\text { Sunu, Ketarap) }\end{array}$ \\
\hline
\end{tabular}

terkendali ${ }^{2}$. Indikator dan Dampak-dampak perubahan iklim terhadap lingkungan sebagai berikut (Priwardhani 2013; dan Diposaptono et.al 2009):

1. Indikator perubahan suhu tahunan dan periode 20 tahun terakhir berdampak sebagai berikut:

a. Melelehnya kutub, sehingga naiknya paras muka air laut

b. Coral Bleaching (kematian \& pemutihan terumbu karang) selain akibat juga dari penggunaan kimia potassium

2. Indikator perubahan volume curah hujan tahunan dan periode 20 tahun terakhir berdampak pada Hujan badai, banjir bandang dan abrasi.

3. Indikator Kenaikan volume air laut berdampak pada genangan di lahan rendah dan rawa, Erosi pantai, Gelombang Ekstrim dan banjir, Intrusi Air laut ke sungai dan air tanah.

Gambar 5 dalam grafik memperlihatkan bahwa telah terjadi kenaikan curah hujan rata-rata pada tahun 2000 dan tahun 2013 dalam kurun waktu 20 tahun dari 1994 - 2014. Kenaikan tertinggi terjadi pada tahun 2000 yakni sebesar 261,1 mm dan tahun 2013 sebesar 262,1 mm. Kenaikan curah hujan rata-rata tiap tahunnya berbeda-beda dan naik turun secara derastis karena posisi geografis Natuna yang memiliki karakteristik khas tertentu. Perubahan iklim pada indikator curah hujan di

2 Freddy Numberi. 2009. Perubahan Iklim: Implikasi terhadap Kehidupan di Laut, Pesisir dan Pulau-Pulau Kecil. Hal-56.
Natuna memilik karakteristik yang khas. Kondisi ini juga dijelaskan oleh informan dari

Forecaster Stasiun Meteorologi Kelas III, AZ (28 th):

“... Kondisi curah hujan di kawasan Natuna ini tergolong kawasan ekuatorial yang unik dimana kondisinya dipengaruhi arah angin laut yang luas. Letak geografis Natuna yang berada dekat dengan laut Cina Selatan menjadikannya memiliki karakteristik yang khas... ... Kondisi Curah hujan pun berbeda dengan daerah monsunal seperti di Jawa. Puncak hujan biasanya terjadi pada musim angin utara atau sekitar bulan DesemberJanuari.."

Pada Gambar 6 terlihat bahwa 87 persen nelayan setuju dengan persepsi bahwa intensitas datangnya badai di laut sering datang secara tiba-tiba. Hal ini memang sering terjadi dan dirasakan oleh nelayan langsung ketika melaut. Menurut nelayan kondisi tersebut sangat membahayakan dan mengganggu aktivitas penangkapan.

Hal ini diakui oleh seorang nelayan bernama SPD (30 tahun):

“...waktu saya melaut, badai yang tiba-tiba datang dan tidak bisa di prediksi menjadi gangguan saya dalam melaut. Hal ini membahayakan keselamatan juga...

Indikator selanjutnya adalah masyarakat pernah menjumpai kenaikan air laut atau intrusi air laut sampai daratan yang dirasa berbeda dari biasanya. Kondisi tersebut jatuh pada musim utara di tahun 2000. Pada tahun 2013 hampir sama kondisinya yakni peningkatan volume air, hanya saja hal ini diakibatkan musim hujan yang tinggi ketika musim utara. Kondisi didaratan pada waktu tersebut sampai terjadi banjir yang mengganggu aktifitas warga. Kondisi tersebut disampaikan oleh seorang informan yaitu kepala BPD, Bapak Een (33 tahun):

“... kenaikan air laut parah ditahun 2000 sampai masuk kepelataran rumah atuk MJ (Rumah yang berada di dekat pantai). Kami kira akan terjadi tsunami. Di tahun 2013 kondisi beda, yaitu hujan yang lebat musim utara menyebabkan banjir walaupun banjir tidak sampai rumah warga. Tapi jembatan anak-anak menuju ke tanjung dan sekolahan penuh air..."

Persepsi Nelayan terhadap Perubahan Iklim dan Hubungannya dengan Karakteristik Nelayan

\section{Hubungan antara Usia dengan Persepsi Nelayan terhadap Perubahan Iklim}

Hubungan antara usia responden dengan persepsi nelayan terhadap perubahan iklim diuji dengan tujuan untuk mengetahui apakah usia yang berbeda mempengaruhi persepsinya terhadap perubahan iklim. Persepsi terhadap perubahan iklim ini meliputi pengukuran tingkat persepsi responden terhadap terjadinya perubahan ekologis di wilayah pesisir serta pengukuran tingkat persepsi responden terhadap dampak-dampak perubahan iklim yang dirasakan. Hasil uji korelasi dengan metode Rank 


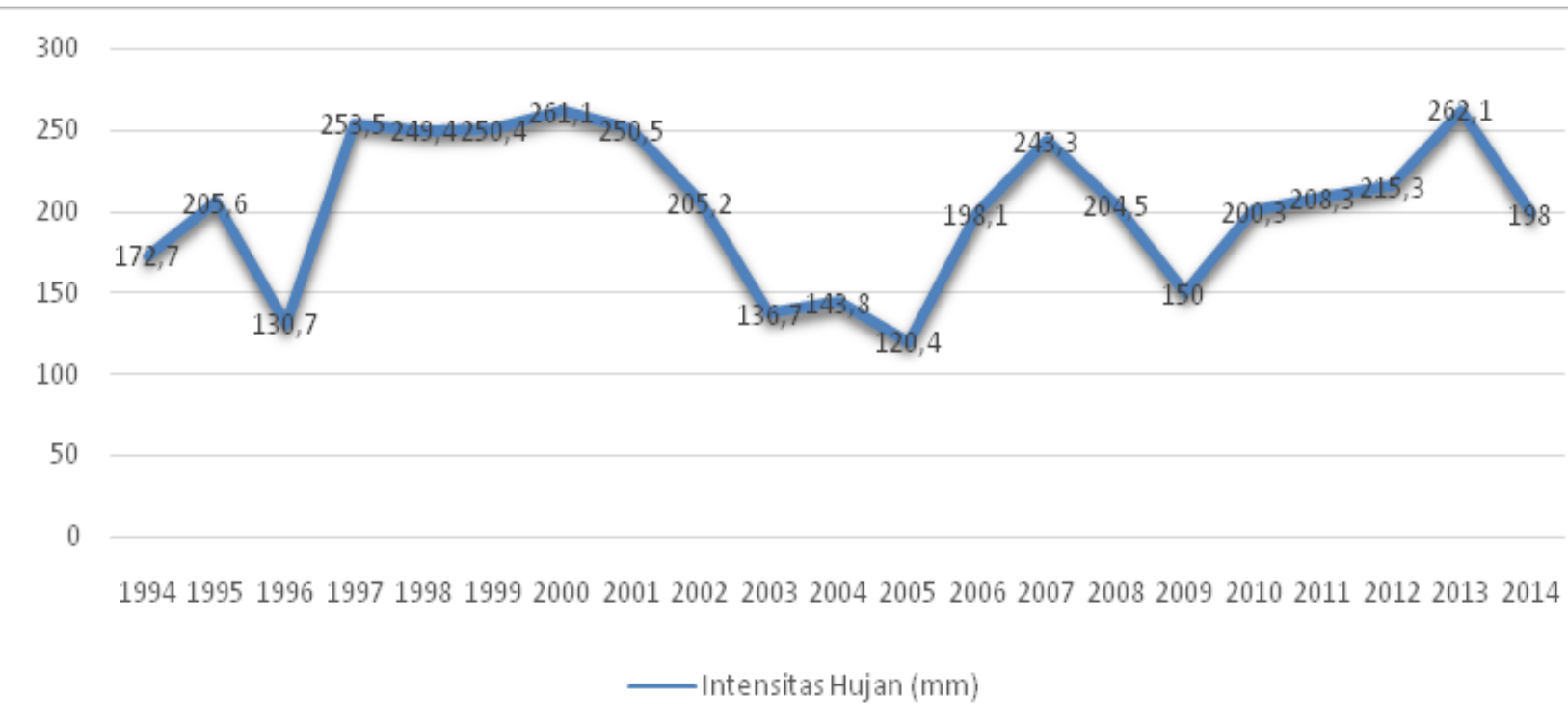

Sumber: Data Stasiun Meteorologi Kelas III Ranai, Natuna 2015

Gambar 5 Grafik Data Curah Hujan Rata-rata Tahunan Kab. Ranai, Natuna dari Tahun 1994 - 2014

Spearman menghasilkan data pada Tabel 9.

Berdasarkan hasil perhitungan didapat signifikansi sebesar 0,051 atau lebih besar dari $\alpha(0,05)$, maka Ho diterima. Artinya, tidak terdapat hubungan yang signifikan antara usia responden dengan persepsi terhadap perubahan iklim. Hal ini menunjukkan persepsi yang tinggi terhadap perubahan iklim tidak ditentukan oleh tua, dewasa ataupun mudanya usia nelayan melainkan faktor kontak langsung nelayan terhadap lingkungan dianggap sebagai faktor berpengaruh. Dalam kenyataan di lapangan, baik nelayan berusia muda, dewasa ataupun nelayan berusia tua sama-sama telah menyadari terjadinya perubahan ekologis di lautan bahkan di dunia atau berpersepsi tinggi terhadap perubahan iklim. Hal tersebut semakin didukung dengan pendapat para nelayan bahwa hasil tangkapan yang semakin sedikit dan kondisi badai yang datang tiba-tiba serta lebih besar dari biasanya. Hal ini diakui beberapa nelayan seperti yang disampaikan oleh Bapak SMN (39 tahun) sebagai wakil komunitas nelayan desa:

“... tahun 2014 kemarin pas musim utara badai datang lebih besar dari biasanya. Sampai rumah gudang Pak $R N$ terangkat gentingnya. Terus si JK pas cari ikan di Pulau belakang juga awalnya laut tenang, tiba-tiba mendung de' dan angina dilaut kencang dan membalik sampannya ..."

\section{Hubungan antara Tingkat Pendidikan dengan Persepsi Nelayan terhadap Perubahan Iklim}

Hubungan antara Tingkat pedidikan responden dengan persepsi nelayan terhadap perubahan iklim diuji dengan tujuan untuk mengetahui apakah perbedaan pendidikan dan tingkat keilmuan individu dapat memberikan pengaruh pada pengetahuan setiap individu dalam menganalisis perubahan-perubahan fisik ataupun gangguan yang terjadi di Pulau Panjang. Hasil hubungan uji korelasi kedua variabel ini dapat dilihat pada Tabel 10 .

Berdasarkan hasil perhitungan didapat signifikansi sebesar 0,043 atau lebih rendah dari $\alpha(0,05)$, maka Ho ditolak. Artinya, terdapat hubungan yang signifikan antara pendidikan responden dengan persepsi terhadap perubahan iklim dan korelasi negatif. Hal ini menunjukkan bahwa untuk menyadari terjadinya perubahan iklim yang berdampak kepada kondisi ekologi pesisir, nelayan yang berpendidikan rendah lebih memahami dampak perubahan iklim dari pada yang berpendidikan sedang. Korelasi terbalik muncul terjadi karena kondisi pendidikan nelayan yang rata-rata cenderung rendah dimana 24 orang dari 30 responden atau 80 persen responden dalam penelitian hanya mencapai jenjang pendidikan rendah (tidak sekolah sampai tamat Sekolah Dasar), 6 orang dari 30 responden atau 20 persennya perpendidikan sedang, dan tidak terdapat nelayan yang berpendidikan tinggi, tetapi nelayan walau hanya berpendidikan rendah dan sedang telah mampu menginterpretasikan perubahan ekologis yang terjadi di lautan sebagai dampak perubahan iklim.

\section{Hubungan antara Tingkat Lamanya Bekerja Nelayan dengan Persepsi Nelayan terhadap Perubahan Iklim}

Hubungan antara lamanya responden bekerja dengan persepsi nelayan terhadap perubahan iklim sebagai nelayan diuji dengan tujuan untuk mengetahui apakah persepsinya terhadap perubahan iklim dipengaruhi oleh perbedaan pengalaman lama-tidaknya menjadi nelayan menjadikan perbedaan cara pandang dalam menilai perubahan iklim pada setiap individu responden Hasil perhitungan korelasi kedua variabel ini dilihat dalam Tabel 11.

Berdasarkan hasil perhitungan didapat signifikansi sebesar 
0,432 atau lebih besar dari $\alpha(0,05)$, maka Ho diterima. Artinya, tidak terdapat hubungan yang signifikan antara lama bekerja nelayan dengan persepsi terhadap perubahan iklim. Hal ini menunjukkan bahwa untuk menyadari terjadinya perubahan iklim yang berdampak kepada kondisi ekologi pesisir nelayan tidak membutuhkan lama bekerja nelayan tertentu. Sebanyak 29 nelayan mempersepsikan tinggi terhadap perubahan iklim. Hal ini dirasa faktor kontak langsung nelayan dengan kondisi perubahan lingkungan sangat berpengaruh pada aktifitas nelayan, baik yang lamanya menjadi nelayan rendah, sedang ataupun tinggi.

\section{Hubungan antara Jumlah Anggota Rumah Tangga dengan Persepsi Nelayan terhadap Perubahan Iklim}

Hubungan antara jumlah anggota rumah tangga nelayan dengan persepsi nelayan terhadap perubahan iklim diuji dengan tujuan untuk mengetahui apakah persepsinya terhadap perubahan iklim dipengaruhi besarnya anggota rumah tangga yang dimiliki nelayan, semakin besar anggota rumah tangga maka pengetahuan dan cara pandang menilai perubahan iklim akan berbeda, karena dalam tambahan anggota keluarga diasumsikan memilik pengaruh tambahan informasi kepada responden dalam memandang perubahan iklim. Hasil perhitungan korelasi kedua variabel ini dilihat dalam Tabel 12.

Berdasarkan hasil perhitungan didapat signifikansi sebesar 0,702 atau lebih besar dari $\alpha(0,05)$, maka Ho diterima. Artinya, tidak terdapat hubungan yang signifikan antara Besar jumlah anggota rumah tangga dengan persepsi terhadap perubahan iklim. Hal ini menunjukkan bahwa untuk menyadari terjadinya perubahan iklim yang berdampak kepada kondisi ekologi pesisir nelayan tidak membutuhkan bauran informasi dari keluarga. Sebanyak 29 nelayan mempersepsikan tinggi terhadap perubahan iklim. Hal ini dirasa faktor kontak langsung nelayan sendiri dalam merasakan pengaruh perubahan iklim pada aktifitas penangkapan mereka, hampir dirasakan seluruhnya oleh nelayan.

\section{Persepsi Nelayan terhadap Perubahan Iklim dan Hubungannya dengan Strategi Adaptasi Nelayan}

\section{Strategi Adaptasi Nelayan}

Menurut Murdiyarso (2005), adaptasi terhadap perubahan iklim adalah salah satu cara penyesuaian yang dilakukan secara spontan maupun terencana untuk memberikan reaksi terhadap perubahan iklim. Selanjutnya Smit dan Wandel (2006) menjelaskan bahwa adaptasi termasuk tindakan yang diambil untuk mengurangi kerentanan dan meningkatkan resiliensi, sedangkan kemampuan adaptasi adalah kemampuan untuk mengambil tindakan tersebut. Smit dan Wandel (2006) juga melihat adaptasi pada aspek tindakan yang dilakukan serta seberapa besar kemampuan yang dilakukan dalam mengambil tindakan tersebut.

Nelayan dalam menghadapi perubahan iklim, mereka banyak melakukan strategi adaptasi atau penyesuaian antara lain pada aspek ekonomi nelayan melakukan diversifikasi kegiatan ekonomi. Dalam aspek teknologi penangkapan nelayan melakukan penganekaragaman alat tangkap. Adaptasi pada aspek teknik penangkapan, nelayan melakukan mengubah area penangkapan (fishing ground). Adaptasi yang dilakukan pada aspek sosial budaya nelayan melakukan pemanfaatan jaringan sosial dan melakukan mobilisasi anggota keluarga untuk turut ikut bekerja.

\section{Diversifikasi Kegiatan Ekonomi}

Upaya yang dilakukan nelayan dalam menjaga kestabilan danpemenuhan ekonomi, mereka melakukan ragam kegiatan ekonomi yang dapat menambah hasil ekonomi keluarga. Kondisi yang terjadi di Pulau Panjang, sebanyak 29 responden dari 30 total responden melakukan pekerjaan bukan hanya sebagai nelayan, melainkan mengkombinasikan dengan pekerjaan lain. Ragam mata pencaharian yang dimasuki oleh para nelayan diantaranya petani kebun kelapa dan cengkeh, budidaya ikan hidup (waring laut), buruh bangunan.

Tabel 2 sebelumnya terlihat musim nelayan melakukan kerja diluar sektor perikanan khususnya pada musim utara. Pekerjaan tambahan seperti proyek bangunan lebih banyak pada bulan-bulan September sampai Maret. Pada bulan tersebut nelayan bergantian mengerjakan proyek bangunan dari pemerintah desa. Proses pergantiannya adalah per-RT akan mendapat jatah untuk mengerjakan proyek dalam waktu 1 minggu sesuai jumlah tenaga kerja yang di butuhkan dari kontraktor. Pekerjaan lainnya adalah kerja kebun kelapa dan kebun cengkeh, nelayan merasa untuk menunjang pengeluaran kebutuhan mereka harus melakukan penganekaragaman pekerjaan. Pekerjaan kebun kelapa dan cengkeh adalah salah satu penunjang ekonomi masyarakat Pulau Panjang.

Kondisi geografi rumah masyrakat Pulau Panjang rata-rata memiliki halaman yang luas dan jarak antar rumah ke rumah terpisah-pisah atau tidak sejajar. Halaman tersebut ditanami tanaman kelapa oleh masyarakat. Minimal masyarakat memiliki 20-30 batang kelapa yang mengelilingi rumahnya. Dalam satu tahun masyarakat dapat melakukan pemanenan 3-4 kali atau tiga bulan sekali. Kelapa-kelapa ini setelah di panen akan akan diambil kopranya dan disalai (di panggang dengan asap serabut dan batok kelapa kering). Hasil panggangan kopra ini masyarakat menyebutnya niok. Harga jual niok ini per kilogram Rp 4.800,00 sampai Rp 6.000,00. System sosial ekonomi kerja kelapa adalah biasanya pemilik kebun (nelayan yang memiliki kebun) bagi hasil sesuai kesepakatan dengan penggarap (biasanya nelayan yang tidak memiliki lahan dan kebun melakukan pemanenan sampai sampai menjadi menjadi niok).

Selain melakukan pemanenan kebun kelapa nelayan juga melakukan kerja cengkeh. Tanaman cengkeh ini adalah tanaman tahunan yang dipanen setiap 3-4 tahun sekali. Kondisi sosial ekonomi nelayan melakukan pekerjaan ini sama dengan sistem kerja kelapa, yaitu nelayan yang memiliki kebun cengkih biasanya melakukan bagi hasil dengan penggarap (nelayan yang melakukan pemanenan atau disebut panjat cengkeh). Harga jual cengkeh per kilogram adalah Rp 100.000,00. Pekerjaan kebun pada umumnya akan maksimal menjadi fokus nelayan untuk 
melakukan pekerjaan ketika terjadi musim utara. Pada gambar 4 di halaman sebelumnya terlihat bahwa nelayan yang melakukan diversifikasi kegiatan ekonomi dengan bekerja diluar sektor perikanan tangkap seperti kebun kelapa, cengkeh, dan tukang. Mereka cenderung akan mendapatkan penghasilan antara Rp. 50.000,00 sampai bahkan diatas Rp. 3000.000,00. Sedangkan nelayan yang hanya bekerja sebagai nelayan saja mereka terlihat tidak mendapatkan penghasilan tambahan atau sebesar Rp 0,00.

\section{Penganekaragaman Alat Tangkap}

Usaha nelayan untuk mendapatkan hasil tangkapan yang maksimal, nelayan merasa perlu menambah jumlah alat tangkap. Pada umumnya nelayan di Desa Pulau Panjang adalah nelayan kecil. Nelayan melakukan penangkapan dengan teknologi sederhana dan sesuai kondisi ekonomi mereka. Alat tangkap standar yang dimiliki adalah pancing ulur, selain pancing ulur nelayan juga mengkombinasikan dengan alat tangkap seperti bubu ${ }^{3}$, jaring, tikam (singkap), alat selam. Penggunaan alat tangkap tersebut disesuaikan dengan minat nelayan. Pada Tabel 13 dapat diketahui jenis alat tangkapan dan jenis hasil tangkapan nelayan Desa Pulau Panjang.

Penganekaragaman alat tangkap dilakukan nelayan mulai tahun 2000 sampai sekarang, hal ini karena nelayan rasa kondisi alam mulai berubah dan cuaca yang mulai berubah-ubah mengakibatkan pendapatan mereka mulai menurun. Sebelum tahun 2000 pada umumnya nelayan hanya menggunakan pancing ulur saja untuk menangkap ikan dilaut atau satu jenis alat tangkap lain saja kecuali alat tangkap tikam. Alat tangkap tikam ini digunakan nelayan untuk penangkapan di sekitar wilayah pantai saja atau untuk tambahan pendapatan.

\section{Mengubah Daerah Tangkapan (Fishing Ground)}

Adaptasi ini dilakukan hanya dengan mengandalkan naluri dan pengalaman mendeteksi area yang diperkirakan banyak ikan. Nelayan pada umumnya belum menggunakan teknologi GPS karena keterbatasan modal. Hal ini menyebabkan inefisiensi energi, pemborosan waktu, dan hasil tangkapan yang rendah. Area penangkapan yang biasanya 5 sampai 10 mil dari bibir pantai Desa Pulau Panjang, sekarang dapat melebihi hal tersebut jarak tersebut. Area fishing ground kadang sampai di kawasan Pulau Kecamatan Serasan dan Pulau Kecamatan Subi. Berikut pemaparan salah satu nelayan, SPD (30 tahun):

“... Dulu kita hanya beberapa kilo dari pantai ikan
banyak, sekarang ikan sedikit. Kita melaut bisa sampe

3 Bubu merupakan jenis alat tangkap berupa perangkap yang terbuat dari bambu dan kawat besi yang biasanya bertempat di area karang dasar laut. Penempatan Bubu di lakukan pada area sekitar karang agar Bubu tersebut tidak terbawa arus dan ikan karang terjebak masuk ke dalam perangkap. Beberapa ikan mahal biasanya banyak bersembunyi di wilayah karang.

4 Tikam atau singkap adalah jenis alat tangkap berbentuk tombak yang area penangkapannya hanya berada disekitar bibir pantai atau wilayah karang dangkal.
Subi dan dekat laut Serasan ${ }^{5} . . "$

\section{Pemanfaatan Jaringan Sosial}

Adaptasi yang dilakukan dengan meminta bantuan pada saat kondisi kesulitan atau paceklik. Kondisi paceklik bagi nelayan Desa Pulau Panjang biasanya terjadi pada musim-musim angin utara. Nelayan pada musim utara pada umumnya tidak dapat bekerja di laut. Karena pada umumnya perahu atau pompong ${ }^{6}$ yang mereka gunakan adalah pompong kecil antar $0-3$ GT dalam kegiatan penangkapan ikan. Pada kondisi musim utara nelayan biasanya memanfaatkan hubungan-hubungan sosial untuk menghadapi musim-musim tersebut. Hubungan tersebut bukan hanya melibatkan dua individu, melainkan juga banyak individu yang kemudian akan membentuk jaringan sosial.

Menurut Kusnadi (2000) berdasarkan status sosialekonomi rumah tangga nelayan yang terlibat dalam suatu jaringan, terdapat dua jenis hubungan sosial, yaitu hubungan sosial yang bersifat vertikal dan horizontal. Jaringan sosial vertikal terwujud dalam bentuk ikatan patron-klien antar boss (biasa diartikan juragan atau toke) dengan nelayan. Peran boss berada pada permodalan, selain pemberian modal menurut nelayan bahwa yang menanggung ketika paceklik nelayan tidak dapat melaut adalah boss-boss mereka. Semua nelayan hampir menyatakan hal yang sama. Berikut pernyataan salah satu perwakilan nelayan, EDS (34 tahun):

“...Biasanya bang, kalau musim utara nelayan disini rata-rata tidak kerja melaut. Mereka yang punya boss biasanya dapat bantuan sembako dari boss. Boss juga biasanya kasih pinjaman kita baik uang dan lain-lain..."

Selain hubungan sosial vertikal, nelayan juga memanfaatkan hubungan sosial horizontal. Hubungan sosial horizontal ini tercermin dengan saling bantu antar nelayan dengan tetangga atau nelayan yang memiliki mata pencaharian sampingan di darat. Hal ini terlihat pada sistem kerja Kelapa dan Cengkeh. Nelayan yang tidak memiliki lahan atau pohon kelapa biasa melakukan penggarapan kebun pada nelayan atau warga yang memiliki lahan kelapa yang luas. Sistem upahnya biasanya bagi dua antara pemilik dan penggarap sampai hasil penjualan dalam bentuk kopra. Apabila yang menggarap kebun kelapa ada dua orang, maka pembagian pemilik tetap 50 persen dan 50 persennya di bagi dua antar dua orang penggarap. Sistem penggarapan kelapa adalah pemanenan, pemecahan kelapa sampai penjemuran menjadi kopra atau niok ${ }^{7}$. Biasanya kalau musim-musim biasa,

5 Subi dan Serasan adalah pusat-pusat kecamatan, sedangkan Desa Pulau Panjang sendiri secara administrasi berada di kecamatan Subi. Jarak Desa Pulau Panjang ke Pusat Kecamatan Subi dan Serasan hampir sama, yaitu sekitar 20 mil dan harus ditempuh perjalanan laut atau sekitar 3 jam dengan pompong.

6 Pompong adalah sebutan untuk perahu kayu nelayan dengan design mesin dalam (inboard engine). Biasanya pompong yang dimiliki nelayan berukuran 0,5 GT dan maksimal 30 GT. Rata-rata nelayan di kawasan Kecamatan Subi khususnya Desa Pulau Panjang hanya memiliki pompong berukuruan GT kecil (0,5 GT - 3 GT).

7 Niok adalah sebutan untuk kopra atau hasil dari daging buah 
kebun kelapa bukan menjadi fokus nelayan dalam bekerja. Harga jual niok per kilogram adalah sekitar Rp. 5.000,00 Rp. 6.000,00. Dalam satu pohon biasanya dapat dipanen 1 -2 kilogram kopra jadi.

Selain kebun kelapa, di tahun-tahun tertentu setiap tiga tahun sekali nelayan juga melakukan kerja cengkeh. Biasanya pemanen kebun cengkeh atau tanaman tahunan ini dilaksanakan pada musim utara antara bulan oktober sampai januari. Sistem pengerjaan biasa disebut panjat cengkeh atau pemetikan dan pengumpulan cengkeh yang jatuh ke tanah. Sistem bagi hasil keuntunganpun sama dengan sistem bagi dalam kerja kelapa. Harga jual cengkeh per kilogram adalah Rp. 100.000,00.

\section{Memobilisasi Anggota Keluarga}

Strategi lain yang dilakukan nelayan dalam menghadapi perubahan iklim adalah memobilisasi anggota keluarga. Nelayan di Desa Pulau Panjang biasanya melakukan mobilisasi atau mengikut sertakan anggota keluarga dalam bekerja. Nelayan di Pulau Panjang banyak yang mengajak anak yang libur sekolah, istri atau kerabat untuk bekerja bersama seperti saat melakukan pukat, mengolah dan panen kebun. Hal ini dilakukan untuk efisiensi tenaga kerja bayaran dan tenaga kerja keluarga biasanya tidak perlu dibayar. Dalam melakukan kegiatan penangkapan dengan pukat ada beberapa nelayan yang mengajak anggota keluarga untuk ikut melaut. Berikut salah satu pernyataan nelayan, Bapak PND (41 th):

“... Biasanya saya melaut mengajak anak saya pas libur sekolah, ini melatih anak saya untuk melaut dan biar tidak terlalu lama dalam bekerja...selain itu kadang saya juga ajak anak saya yang kuliah atau istri buat kerja kelapa..."

Selain membantu dalam bekerja di kebun dan di laut. Perempuan nelayan juga memiliki pekerjaan untuk membantu suami dalam mencukupi kebutuhan. Pekerjaan yang dilakukan perempuan atau istri nelayan antara lain berjualan makanan olahan dari ikan, mengisi karung atau membantu suami mengambil pasir pantai untuk bangunan, membuat tikar pandan, membuat kerupuk, dan ada juga yang mencari pangsik (sejenis kerang yang menempel di karang laut).

Makanan olahan dari ikan yang biasa di jual adalah bakso ikan, kerupu ikan, kernas (makanan olahan khas natuna), dan bakwan ikan. Perhari biasanya istri nelayan dapat mengantongi uang Rp. 40.000,00 - Rp. 60.000,00 dari hasil penjualan. Ada juga istri nelayan yang membantu suaminya mencari pasir di pantai untuk bahan bangunan. Biasanya untuk pengumpulan pasir atau batu perbulan istri nelayan dapat mendapatkan penghasilan Rp. 300.000,00. Penghasilan lain adalah biasanya istri nelayan ada yang membuat kerajinan tikar pandan dengan Rp. 150.000,00 jika dijual. Istri nelayan biasanya dapat mengantongi penghasilan Rp. 70.000,00 per kilogram dari pembuatan

kelapa yang telah dikeringkan dengan proses salai (Pengasapan) dan penjemuran. dan kerupuk ikan. Pekerjaan terakhir istri nelayan adalah mencari pangsik ${ }^{8}$ yang sebagian besar di temukan di karang, harga jual per kilogramnya biasanya Rp.8.000,00 dan pangsik digunakan sebagai makanan olahan.

\section{KESIMPULAN DAN SARAN}

\section{Kesimpulan}

Perubahan iklim memberi pengaruh pada aspek sosial ekonomi nelayan. Gangguan pada aspek sosial ekonomi nelayan tersebut, antara lain:

1. Perubahan Kelender Musim Tangkap dahulu ( $<$ tahun 2000) dan sekarang ( $\geq$ tahun 2000) pada Nelayan Pulau Panjang. Hasil tangkapan musim sekarang sangat sedikit dibanding tahun-tahun terdahulu.

2. Hilangnya beberapa hewan yang menjadi penanda pergantian musim oleh nelayan.

3. Peningkatan intensitas terjadinya badai di laut yang datang secara tiba-tiba dan tidak dapat diprediksi, hal tersebut berpengaruh pada aktifitas penangkapan. Nelayan merasakan bahaya yang datang secara tibatiba dan gangguan pada saat menangkap ikan dilaut.

Persepsi nelayan terhadap perubahan iklim adalah penafsiran nelayan terhadap perubahan-perubahan ekologis yang terjadi di wilayan pesisir sebagai dampak dari perubahan iklim yang terjadi di Desa Pulau Panjang. Data yang diperoleh dari survai terhadap 30 orang nelayan menunjukkan bahwa hampir seluruh nelayan (96,7 persen atau 29 orang) telah mempersepsikan perubahan iklim terjadi wilayah Desa Pulau Panjang. Hanya satu orang saja diantaranya 3,3 persen responden yang memiliki persepsi yang sedang, tidak ada responden yang berpersepsi rendah terhadap perubahan iklim. Sedangkan dari uji korelasi Rank Spearman yang dilakukan antara persepsi nelayan terhadap perubahan iklim dengan berbagai variabel karakteristik individu, tidak ditemukan satupun hubungan yang signifikan kecuali pada variabel pendidikan pada karakteristik individu. Hal ini disebabkan oleh beberapa faktor, yaitu:

1. Dampak perubahan iklim telah jelas terjadi di laut dan pesisir Desa Pulau Panjang. Seluruh masyarakat telah membentuk persepsi yang sama mengenai perubahan iklim dengan tidak memandang usia, lamanya menjadi nelayan, dan besarnya jumlah anggota keluarga. Faktor karakteristik individu yang berkorelasi adalah tingkat pendidikan nelayan dan korelasi yang terlihat adalah korelasi negative (Semakin rendah pendidikan nelayan hubungannya semakin tinggi persepsinya). Hal ini dikarenakan sebaran yang tidak merata pada data responden dan karakteristik nelayan yang homogeny. Nelayan di Pulau Panjang adalah nelayan berpendidikan rendah, sedang dan tidak ada nelayan yang berpendidikan tinggi. Nelayan yang berpendidikan rendah dan sedang ini sama-sama mepersepsikan tinggi terhadap perubahan iklim.

8 Pangsik adalah sejenis kerang yang menempel di karang. Cara mendapatkannya adalah dengan menggunakan alat tusuk (tikam). Pangsik sangat digemari warga natuna sebagai makanan olahan khas. 
2. Eratnya hubungan (kontak langsung) antara nelayan dengan sumberdaya laut, sehingga berbagai perubahan ekologis yang terjadi dilaut telah ditafsirkan secara mandiri oleh nelayan sebagai dampak perubahan iklim.

3. Hasil uji korelasi dengan crosstabs pada spss 1.6 for windows antara peresepsi terhadap terjadinya perubahan iklim dengan pilihan strategi adaptasi nelayan, juga terlihat tidak terdapat hubungan yang signifikan. Artinya persepsi terhadap perubahan iklim bukan menjadi alasan utama untuk melakukan strategi adaptasi. Hal ini disebabkan karena kondisi dilapangan ternyata memperlihatkan bahwa nelayan melakukan strategi adaptasi diversifikasi kegiatan ekonomi (A), penganekaragaman alat tangkap (B), mengubah daerah tangkap (C), pemanfaatan jaringan sosial (D), dan memobilisasi anggota keluarga (E) bukan bukan semata karena persepsi perubahan iklim yang tinggi menentukan pilihan strategi adaptasinya, melainkan nelayan merasa perlu strategi adaptasi lebih dari satu tersebut dikarenakan kondisi lingkungan Pulau Panjang yang mulai berubah. Kontak secara langsung dengan lingkungan dan anomaly cuaca yang biasa terjadi seperti peningkatan musim utara (angin kencang) dan pola cuaca yang sulit diperediksi, nelayan merasa perlunya strategi adaptasi untuk menghadapi kondisi paceklik tersebut.

Strategi Adaptasi yang dilakukan nelayan terlihat pada beberapa aspek yang dilakukan oleh nelayan dalam mengatasi dampak ekonomi yang salah satunya ditimbulkan oleh perubahan iklim. Adaptasi dan strategi tersebut meliputi:

1. Pada Aspek Ekonomi, nelayan melakukan diversifikasi kegiatan Ekonomi.

2. Pada Aspek teknologi penangkapan, nelayan melakukan penganekaragaman alat tangkap.

3. Pada Aspek teknik penangkapan, nelayan melakukan perubahan area fishing ground atau daerah tangkap.

4. Pada Aspek sosial budaya, nelayan memanfaatkan jaringan sosial dan memobilisasi anggota keluarga untuk bekerja.

\section{Saran}

1. Perlu dorongan yang bersifat antisipatif kepada nelayan dan masyarakat Pulau Kecil terkait strategi mitigasi terhadap kebencanaan khususnya di wilayah Desa Pulau Panjang. Apabila di prediksi ketika terjadi bencana, kondisi wilayah pulau kecil seperti Desa Pulau Panjang sangat beresiko tinggi ketika terjadi bencana. Kondisi geografis wilayah Desa Pulau Panjang yang datar tidak ada perbukitan dan kondisinya yang jauh dari pusat pemerintahan baik kecamatan dan kabupaten, diharapkan perlu perhatian lebih terkait antisipatif kebencanaan akibat perubahan iklim.

2. Kebijakan permodalan yang dilakukan secara sinergis antara masyarakat dengan pemerintah selaku pemberi kebijakan dirasa sangat penting terkait dukungan strategi adaptasi diversifikasi kegiatan ekonomi (pola nafkah ganda). Potensi desa Pulau Panjang yang sangat prospektif untuk di kembangkan (Wisata, Sumberdaya Lokal, Kerajinan, dil) perlu di perhatikan. Posisi Natuna khususnya di Pulau Panjang yang berada di ujung perbatasan sangat potensi dalam menyambut wisatawan asing untuk berwisata alam laut.

3. Perlu penelitian lebih lanjut terkait perubahan ekologi dan coremaps potensi sumberdaya alam laut di desa Pulau Panjang dan area Kecamatan Subi. Karena terkait data penelitian ini, peneliti sangat sulit mencari data ekosistem laut dan kerusakannya khususnya yang terjadi di Desa Pulau Panjang. Hal ini sangat dimaklumi, karena pengembangan coremaps Kabupaten Natuna masih berfokus di Ranai, atau kepulauan besarnya. Selain itu Kabupaten Natuna masih kabupaten baru yang melakukan pemisahan dengan Kabupaten Anambas semenjak 2008, hal ini tentu terjadi perbaikan sistem pemerintahan yang perlu ditingkatkan.

4. Penelitian lebih lanjut terkait pengembangan nafkah nelayan Pulau-pulau Kecil berperspektif kearifan lokal dan keberlanjutan. Hal ini terkait pemanfaat ekonomi kelautan di Pulau Panjang yang masih cenderung eksploitatif. Kondisi di Desa Pulau Panjang beberapa nelayan di kawasan ini masih menggunakan potassium dalam melakukan penangkapan. Nelayan merasa butuh solusi dan introduksi inovasi cara penangkapan yang ramah lingkungan, tentunya dengan biaya yang murah dan berperspektif lokal bukannya pelarangan semata.

\section{DAFTAR PUSTAKA}

Aulia TOS, Dharmawan AH. 2010. Kearifan lokal dalam pengelolaan sumberdaya air di Kampung Kuta. Sodality [Internet]. [diunduh 2015 Februari 1]; 4(3): 345-355. Tersedia pada: https://journal.ipb. ac.id/index.php/sodality/article/view/5839/4504 .

Baron RA, Byrne D. 2004. Psikologi Sosial Jilid 1. Edisi Kesepuluh. Jakarta (ID): Pratama Gelora Aksara. 307 hal.

Borberg J. 2009. Climate Change Adaptation: Information Needs, Concerns, and Behavioral Intention among Oregon Coast Professionals [internet] [8 Januari 2015]. Dapat diunduh dari: https://ir.library.oregonstate.edu/xmlui/ bitstream/handle/1957/14275/Bor berg_MRM_ Project_25Aug09.pdf?sequence $=1$.

Diposaptono $\bar{S}$, Budiman, Firdaus A. 2009. Menyiasati Perubahan Iklim di Wilayah Pesisir dan PulauPulau Kecil. Bogor (ID): PT. Sarana Komunikasi Utama.

Helmi A, Satria A. 2012. Strategi Adaptasi Nelayan Terhadap Perubahan Ekologis. Journal UI Makara [Internet]. [diunduh 10 November 2014]; 16(1) : 68-78. Depok (ID). Dapat diunduh di http://journal.ui.ac.id/index.php/humanities/ article/view/1994.

Hidayati D. 2011. Adaptasi \& Mitigasi Masyarakat Pesisir Terhadap Perubahan Iklim dan Degradasi SDL. Adaptasi \& Mitigasi Masyarakat Pesisir : 120-155. Jakarta (ID): Leuser Cita Pustaka.

Kusnadi. 2000. Nelayan: Strategi Adaptasi dan Jaringan 
Sosial. Bandung [ID]: Humaniora Utama Press.

Muflikhati I. 2010. Analisis dan Pengembangan Model Peningkatan Kualitas Sumber Daya Manusia Dan Kesejahteraan Keluarga Di Wilayah Pesisir Provinsi Jawa Barat. [disertasi]. Bogor (ID): Sekolah Pacasarjana, Institut Pertanian Bogor.

Mulyadi. 2007. Ekonomi Kelautan. Jakarta [ID]: PT. Raja Grafindo Persada.

Murdiyarso D. 2005. Sepuluh Tahun Perjalanan Negosiasi Konvensi Perubahan Iklim. Jakarta (ID) : Penerbit Buku Kompas.

Myers DG. 2012. Psikologi Sosial. Edisi ke-10. Tusyani A, Sembiring LS, Gaytri PG, Sofyan PN, penerjemah. Jakarta (ID): Penerbit Salemba Humanika. Terjemahan dari : Social Psychology.

Numberi F. 2009. Perubahan Iklim: Implikasi terhadap Kehidupan di Laut, Pesisir dan Pulau-pulau Kecil. Jakarta (ID): Citrakreasi Indonesia.

Priwardhani. 2013. Ketika Kupu-Kupu Kuning Tak Lagi Muncul: Perubahan Iklim dan Pengetahuan Lokal di Dua Desa Pesisir Kabupaten Ende. Journal Transformasi Sosial - Wacana. 6 (29) : 113-135. Yogyakarta (ID) : Insist Press.

Ross L, Nisbett RE (1991). The Person and The Situation: Perspectives of social psychology [internet]. [dikutip 4 Oktober 2014]. Dapat diunduh dari http://psycnet.apa.org/psycinfo/1991-97382-000.

Rochmayanto Y, Kurniasih P. 2013. Peranan Gender dalam Adaptasi Perubahan Iklim pada Ekosistem Pegunungan di Kabupaten Solok, Sumatra Barat. Journal Analisis Kebijakan Kehutanan [Internet]. [diunduh 10 November 2014]; 10(3) : 203-213. Bogor (ID). Dapat diunduh dihttp://ejournal. forda-mof.org/ejournal-litbang/index.php/JAKK/ article/view/328

Saad S. 2009. Bajo Berumah di Laut Nusantara. Jakarta Selatan (ID) : CoremapII.

Satria A. 2001. Dinamika Modernisasi Perikanan Formasi Sosial dan Mobilitas Nelayan. Jakarta (ID) : Humaniora Utama Press (UHP).

Satria A. 2002. Sosiologi Masyarkat Pesisir. Jakarta Selatan (ID) : PT Pustaka Cidesindo.

Satria A. 2009. Pesisir dan Laut untuk Rakyat. Bogor (ID): IPBPress.

Scoones I. 1998. Sustainable rural livelihoods: A framework for analysis. IDS Working Paper No. 172. Institute of Development Studies, Brighton: University of Sussex. [Internet]. Diakses pada tanggal 22 Desember 2014 https://www.staff.ncl. ac.uk/david.harvey/AEF806/Sconnes1998.pdf .

Sihombing H A. 2003. Analisis Pendapatan Nelayan Menurut Jenis Usaha Di Desa Pangandaran Kabupaten Ciamis. [skripsi]. Bogor [ID]: Institut Pertanian Bogor.

Silalahi U. 2009. Metode Penelitian Sosial. Bandung (ID): PT. Refika Aditama.

Singarimbun M, Effendi S. 1989. Metode dan Proses Penelitian. Singarumbun M, Effendi S, editor. Metode Penelitian Survai. Jakarta (ID): Lembaga Penelitian, Pendidikan, dan Penerangan Ekonomi dan Sosial (LP3ES).

Smit B, Wandel J. 2006. Adaptation, adaptive capacity and vulnerability. Global Environmental Change,
16: 282-92.

Surtiari GAK. 2011. Perubahan Iklim, Potensi Sumber Daya Pesisir-Laut dan Degradasi Lingkungan di Kawasan Teluk Bone. Adaptasi \& Mitigasi Masyarakat Pesisir : 71-101. Jakarta (ID): Leuser Cita Pustaka.

Tompkins EL, Adger WN. 2004. Does adaptive management of natural resources enhance resilience to climate change? Ecology and Society 9(2): 10. [Internet] URL:http://www. ecologyandsociety.org/vol9/iss2/art10. 